Published in Scottish Journal of Geology, 2013, Volume 49, 59-77.

Note that this version of the text does not include the Journal's editorial and proof

corrections

\title{
The mineral prospecting expeditions to the South Atlantic islands and Antarctic Peninsula region made by the Scottish geologist David Ferguson, 1912-1914
}

\author{
P. Stone ${ }^{1} \&$ J. Faithfull ${ }^{2}$ \\ 1. British Geological Survey, Murchison House, West Mains Road, Edinburgh, \\ EH93LA, UK (e-mail: psto@bgs.ac.uk) \\ 2. Hunterian Museum, University of Glasgow, Glasgow G12 8QQ, UK
}

\section{Synopsis}

David Ferguson's mineral prospecting expeditions to South Georgia (1912), the Falkland Islands and the South Shetland Islands (1913-1914), on behalf of the Christian Salvesen whaling company of Leith and now largely forgotten, were early examples of commercially motivated terrestrial exploration in the South Atlantic region. Prior geological knowledge was very limited and Ferguson complemented his unsuccessful prospecting work with attempts to understand the regional geology of the areas that he visited. These interpretations were based on relatively cursory field work undertaken in an arduous environment, and did not prove robust; but the welldocumented specimen collections that Ferguson accumulated provided the basis for excellent and much-cited petrographical accounts by G.W. Tyrrell of Glasgow University. Ferguson had studied geology at the university and the influence of his mentor there, Professor J.W. Gregory, is apparent. In turn, Gregory utilised Ferguson's observations in support of a subsided 'South Atlantic continent', opposing the 'displacement hypothesis' for that region formalised by Alfred Wegener from 1912 onwards. Ferguson’s field notebooks and most of his rock specimens are now 
held by Glasgow University (Archive Services and Hunterian Museum respectively) but he distributed representative specimen collections widely, and these are extant in several other British museums. Specimens were also supplied to, and discussed with, William Speirs Bruce who, following the 1902-1904 Scottish National Antarctic Expedition, took a keen interest in Ferguson’s discoveries.

\section{Introduction}

The austral summer of 1911-1912 saw much scientific activity in high southern latitudes: see Turney (2012) for a recent review. On the 'Pacific' side of Antarctica British and Norwegian expeditions led by Scott and Amundsen competed fatally for the Pole, whilst Australian and Japanese expeditions were also in the field. On the 'Atlantic' side of the continent (Figure 1), Filchner's German expedition had arrived at South Georgia on 13 May 1911 and, after survey and geological work there, sailed south in December only for their ship to become trapped in Weddell Sea pack ice. The expedition was fortunate to escape back to South Georgia late in December 1912.

Against the background of these major expeditions, scientifically well-equipped and carrying serious patriotic expectations, it is easy to overlook the contributions made by individuals working to a very different brief. One such was David Ferguson, a Glasgow-based Scottish mineral prospector employed by the Christian Salvesen whaling company of Leith, to examine the potential for economic mineralisation in the environs of the company's whaling operations around South Georgia, the South Shetland Islands and the Falkland Islands (Figure 1). Ferguson made two voyages to the region accompanying the whaling fleet and, once in his field areas, received local logistical support from small whale-catching vessels. He first travelled to South Georgia for the austral summer of 1911-1912. For his second expedition in the austral summer of 1913-1914 he was based in the Falkland Islands, whence he embarked on a 10-week prospecting voyage around the South Shetland Islands and adjacent coasts of the Antarctic Peninsula. During his prospecting surveys Ferguson did not restrict himself to observations directly relevant to economic mineralisation. Rather, he set out to gain an overall understanding of the geology of the areas visited, which was for the most part little known. Some of his interpretations have proved erroneous, but as 
an initial gathering of information his work served to inform subsequent investigators. His generally negative conclusions as to the economic potential of the rocks have, however, proved well-founded.

Several hundred rock specimens obtained by Ferguson in the course of his South Atlantic and Antarctic investigations are held by the University of Glasgow's Hunterian Museum. Many of the specimens were scientifically described by University staff, notably Prof. J. W. Gregory, and Dr G. W. Tyrrell, and the whole collection was formally presented by the Salvesen Company to the University in 1915. In collaboration with Gregory and Tyrrell, Ferguson published scientific papers describing the geology of South Georgia, jointly in The Geological Magazine (Ferguson et al. 1914) and as a series of individually authored papers in the Transactions of the Royal Society of Edinburgh (Ferguson 1915; Gregory 1915; Tyrrell 1915). Ferguson's geological observations from the South Shetlands and Antarctic Peninsula were published as a scientific paper in the Transactions of the Royal Society of Edinburgh (Ferguson 1921), followed by a detailed description of the specimens that he collected there by Tyrrell (1921). Ferguson did not publish an account of his work in the Falkland Islands. This omission cannot have been due to his lack of success in discovering economic minerals, since his examination of South Georgia and the environs of the South Shetland Islands had produced similarly negative conclusions. For the same reason there would have been no need to suppress his findings on the grounds of commercial confidentiality. Of course, the pressures of the 1914-1918 Great War may well have precluded the adequate working-up of his results (note the delay in publication of the Antarctic results), but it is also possible that discussion of his findings with Gregory and Tyrrell when back in Glasgow, led Ferguson to doubt his original conclusions on the geology of the Falkland Islands. This possibility is more fully discussed later in the paper.

In addition to the specimen collection held by the Hunterian Museum, Ferguson's six field notebooks (together with other documents) are held by the University of Glasgow Archive Services; they are faded and water-damaged in places, but the writing and diagrams are mostly clear and comprehensible. Archival details for the field notebooks are summarised in Table 1, with extracts quoted in this paper identified by the relevant notebook and page number. The notebooks only came to 
light in 2003, when they were passed to the University from the Bank of Scotland archive where they had been held since Ferguson's death in 1936. Additional relevant material is present in the Salvesen Archive, held by Edinburgh University Library's Special Collections Department, and includes some of the photographs taken by Ferguson in South Georgia and the Antarctic, carbon copies of the texts for his formal reports to the Salvesen Company, and copies of various letters discussing his findings written to Mr Theo Salvesen. In this paper, our references to 'Salvesen Report' cite the geographically appropriate document submitted by Ferguson to the company and now held by Edinburgh University Library. Duplicate specimen collections were recorded in Ferguson's notes as having been sent to The Natural History Museum, London, the Sedgwick Museum, Cambridge, and the National Museum, Edinburgh. These collections are all extant, but are exclusively of specimens from the South Shetland Islands and the Antarctic Peninsula.

The presence of Ferguson's specimens in the Hunterian Museum was noted by Durant \& Farrow (1999) in their review of the scientific value of the museum's historical 'ocean island' rock collection; the subsequent reappearance of his accompanying notebooks has added considerably to the value of his specimens. In this paper we assess Ferguson's contribution in terms of the developing regional interpretations of South Atlantic geology, utilising his notebooks and the full range of additional archival material available in Glasgow, Edinburgh, London and Cambridge. We bring to bear personal field experience in South Georgia and the Falkland Islands (PS) and familiarity with the Hunterian Museum collections (JF).

Nothing is known of Ferguson's early years, but his notebooks reveal that he had been active as a mineral prospector and mine surveyor in Iran (1891-1893) Newfoundland (1894) southern Africa (1895-96 and 1901-03), and had also worked as a mine surveyor in the Scottish coalfields. The University of Glasgow archives record that he was born "Glasgow c. 1857" and as a mature student took classes at the Glasgow and West of Scotland Technical College (now the University of Strathclyde) between 1904 and 1907 and at the University of Glasgow between 1905 and 1908. He does not appear to have graduated from either institution, but at the University of Glasgow, where he studied geology and mineralogy, he would have made the contacts with 
Gregory and Tyrrell which were to prove so influential in working-up his observations from the South Atlantic.

\section{South Georgia}

The island of South Georgia is the emergent pinnacle of a continental microplate forming part of the mostly submarine, North Scotia Ridge (Figure 1). It lies about

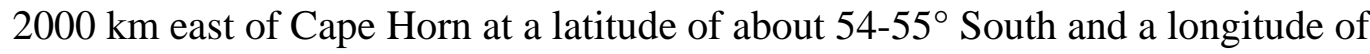
about $36-38^{\circ}$ West. The island has a length of about $170 \mathrm{~km}$ from NW to SE, with a maximum width of about $40 \mathrm{~km}$. The mountainous, glacial interior rises to the $2934 \mathrm{~m}$ summit of Mount Paget, with several other peaks exceeding 2000 m (Figure 2).

The Christian Salvesen Company had established an onshore whaling station in Stromness Bay in 1909, becoming the fourth company to base whaling operations at South Georgia. Their chosen location was named Leith Harbour after the company's home port in Scotland. Negotiations for the mineral rights with the Falkland Islands Government (at that time South Georgia was a Dependency of the Falkland Islands) must have commenced promptly since a formal license for prospecting and mining was signed by the Governor of the Falklands, William Allardyce, on 31 May 1911; the document now forms part of the Salvesen Archive held by Edinburgh University library. Ferguson must have been recruited soon after. Curiously, this would have been Governor Allardyce's second disposal of the South Georgia mineral rights. In 1905, the South Georgia Exploration Company had been formed by British businessmen based in southern Chile and was granted a general mining and grazing lease of the island, but the enterprise was not successful and the company was dissolved (Hunter-Christie 1951, p. 208).

The geology of South Georgia (Figure 2) is summarized by Macdonald et al. (1987) and Curtis (2011). Much of the island is underlain by a thick succession of Lower Cretaceous volcaniclastic sandstone and mudstone (Cumberland Bay Formation), asymmetrically folded and thrust towards the north-east to structurally overlie a more intensely deformed and cleaved succession of quartzose strata (Sandebugten Formation), which may nevertheless be of a similar Cretaceous age (e.g. Stone 
1980). A major shear zone separates these and broadly similar sedimentary rocks (Cooper Bay Formation) from a very different lithological assemblage that forms the south-east end of the island: gneiss intruded by probably Triassic granite (Drygalski Fjord Complex and minor associated metasedimentary formations), Upper Jurassic lavas and volcaniclastic rocks (Larsen Harbour Complex) and Lower Cretaceous tuff (Annenkov Island Formation). In total, the geology of South Georgia illustrates an active continental margin split by the opening of an island arc and backarc basin system, with the subsequent closure of the basin and deformation of its sedimentary fill. Durant \& Farrow (1999) record 205 'Ferguson’ specimens from South Georgia in the Hunterian Museum collection; we can confirm that the great majority are from the Cumberland Bay and Sandebugten formations.

At the time of Ferguson's visit, the geology of South Georgia was largely unknown. The German International Polar Year Expedition (1882-1883) had recorded 'clayslate' and both phyllitic metasedimentary and volcaniclastic rock intruded by dolerite (Thurach 1890), whilst the Swedish Antarctic Expedition (1901-1903) had discovered a probably Early Mesozoic bivalve in a sandstone (Andersson 1907a). When Ferguson arrived, on 7 January 1912, it was only a month after the departure of Filchner's German South Polar Expedition aboard the Deutschland. The Germans had added considerably to the geological knowledge of the islands, including the discovery of igneous rocks in the far south-east. Though Ferguson would have known nothing of the detail of their work, he picked up some information on their findings from staff at the whaling stations. For example, he was shown a sketch of a poorly preserved ammonite supportive of the Mesozoic age previously suggested by Andersson - the possibility of which Ferguson was prematurely dismissive. In support of his fieldwork Ferguson brought to bear considerable practical skill: under difficult conditions he developed photographic plates, prepared thin sections for microscope examination and carried out rudimentary chemical analyses of crushed and panned rock samples.

Stratigraphy and structure in the field

For transport around the island Ferguson was dependent on the whaling ships, usually the small whale catchers (Figure 3), and though he was able to examine most of the 
central and north-western parts of the island's north-east coast, he did not have an opportunity to visit the southern end of the island, and so missed the igneous rocks at outcrop there. He faced the considerable difficulties inherent in South Georgia's topography and weather, and the lack of anything but the most rudimentary of maps required him to triangulate distances and mountain heights as a control on presumed stratigraphical thicknesses. Nevertheless, Ferguson was not slow to advance a broad geological interpretation for the stratigraphy and structure of the sedimentary succession, and the map that he produced was the first such attempt to illustrate the geology of any of the sub-Antarctic islands. But his interpretation would have been hampered by the complex folding, lack of distinctive marker horizons, and paucity of fossil control - so it is perhaps understandable that most of his conclusions proved illusory.

Although he noted and photographed folding at numerous localities (Figure 4), and mentions thrusting several times in his notes and in a single sentence in Ferguson (1915, p. 812), the implications of such deformation are largely ignored in the geological map and cross-section that he constructed (Ferguson 1915, Plates 81 and 82). Instead, Ferguson saw the sedimentary succession as a conformable series of three divisions, which he differentiated largely on the basis of colour. In one relatively small area of the island he thought that the middle division lay unconformably on much older sedimentary strata with a more complex structural history. Ferguson was characteristically confident of his interpretation, writing in his notes (Notebook 2, page 61: 23 Feb 1912): “That the rocks stained dull rusty brown are unconformable to those stained a dull white to greyish white admits of no doubt whatever.” He was partially correct in that at Godthul (Ferguson uses 'Cape George Harbour' for this locality) and around Royal Bay (Figure 2) an intensely folded and cleaved succession (now assigned to the Sandebugten Formation), has been overthrust by a less deformed succession (now assigned to the Cumberland Bay Formation), but there is no unconformity. In these areas and more generally, Ferguson's reliance on colour for correlation led to unlikely outcrop patterns, in places requiring horizontal beds over considerable areas. This structural arrangement was demonstrably absent and it is odd that Ferguson's experienced mentors at Glasgow University, Gregory and Tyrrell, did not identify this fundamental problem prior to their joint publications. Perhaps Tyrrell's focus was entirely on petrography, whilst in his comprehensive biography of 
Gregory, Leake (2011, p. 146) notes that the interpretations of South Georgia “ ... reveal Gregory’s poor knowledge of structural geology.”

Despite Gregory and Tyrell's reticence or oversight, it was not long before Ferguson's misinterpretation was pointed out. Shackleton's ill-fated Endurance expedition had called at South Georgia on its voyage south in November 1914, and the expedition's geologist, J. M. Wordie (another of Gregory’s protégés), had done much geological work during a stay of about four weeks. Wordie’s South Georgia specimens were lost when the Endurance was subsequently crushed by pack ice and sank in the Weddell Sea. The remarkable story of hardship and survival that followed is a now well-known epic of Antarctic exploration which saw most members of the expedition, including Wordie, marooned on Elephant Island; the rock specimens that he collected during his sojourn there are also held by the Hunterian Museum. Meanwhile, Shackleton and a few companions sailed an open lifeboat to the south coast of South Georgia and then made the first crossing of the island's mountainous interior to seek help at the whaling stations in Stromness Bay. Despite all he had been through, Wordie eventually published a summary of his geological observations in which he dismissed Ferguson's "unfortunate attempt at subdividing the sedimentary series" (Wordie 1921, p. 19). In support of his view that Ferguson had ignored structural complications, Wordie included a sketch (his figure 1) and photograph (his plate II, figure 1) of some large scale overturned folds (this paper Figure 4) that had also, perhaps unbeknown to him, been photographed by Ferguson but not used to illustrate the latter's 1915 paper. Ferguson's photograph is underexposed and rather dark, but a print and the glass plate negative are held in the Salvesen Archive, University of Edinburgh Library (photographic archive reference 7627c). By the time Wordie published, Shackleton had embarked on his final expedition (during which he died, at South Georgia, on 5 January 1921 aboard the Quest, with G. V. Douglas as geologist. In that expedition's report, Douglas (1930, p. 9) noted with respect to the geology of South Georgia: “J. M. Wordie’s paper ... appeared after the Quest had sailed, and the present writer arrived independently at the conclusions to which Wordie had also come.” Even Tyrrell joined in, stating in his contribution to the Quest expedition report (Tyrrell 1930, p. 48 and p. 50) that Ferguson's attempt at stratigraphical subdivision “... is certainly premature and at present has little to recommend it” and confirming that he 
“... agrees with Wordie that the supposed unconformities detected by Ferguson are more readily explained as overthrusts, low-angle faults, or monoclinal flexures.”

Palaeontology and the age of the succession

Ferguson's problems with stratigraphy were compounded by the scarcity of useful fossils. His notes make clear that he quickly formed an opinion that the sedimentary rocks were most likely of Early Palaeozoic age, an opinion probably influenced by their superficial similarity to the Ordovician and Silurian strata of the Scottish Southern Uplands with which he would have been familiar. Soon after arriving on South Georgia, Ferguson began to find features that would now be regarded as trace fossils of animal origin; some he speculatively identified as "annelid or worm burrowing” but others were described as the impressions of marine algae or 'fucoids' In this he was rather out-of-date. In the mid-Victoran era many records of trace fossils, crawling/feeding tracks or worm-burrows, were then interpreted as 'fucoids' (after the present-day Fucus, a very common genus of substantial brown seaweed). Around 1860 the British palaeontologist J. W. Salter protested that the 'fucoid' interpretation was dubious and that the features were more likely to be worm burrows. It took some time for the revised opinion to be generally accepted, but it is nevertheless surprising that in describing Ferguson’s ‘fossils', Gregory (1915) should still refer to one as "one of those plant-like impressions which are conveniently regarded as fucoids”. Gregory described other examples from Ferguson’s collection as sponge-like organisms, but these prove to be a radiating network of branching burrows of the Chondrites type (Figure 5), not too dissimilar to Ferguson's field identification as “annelid or worm burrowing”. Gregory’s misidentifications are unexpected in view of his high reputation as a palaeontologist. Ferguson's fossil collection also included a highly dubious ‘coral', likened to Omphyma by Gregory but quite possibly an artefact of veining and weathering. The whole assemblage was thought to be of Early Palaeozoic aspect. It was subsequently reinterpreted as a trace fossil ichnofauna, compatible with a Mesozoic age, by Wilckens (1932) who examined similar material from South Georgia collected by the 1927-1928 Norwegian Antarctic Expedition. 
With Ferguson's predilection for an Early Palaeozoic age it is not surprising that he thought he might have found a graptolite, though to be fair he expressed some doubt as to the specimen's authenticity (Notebook 2, p 154) and did not mention it subsequently. Gregory was more enthusiastic about the specimen, writing (1915, p 819) “... if found in a graptolitic bed [it] would be regarded as a piece of a monoprionid graptolite ... and this opinion is shared by several members of the geological school of this University who have had experience in collecting graptolites in our Southern Uplands.” We have not been able to identify this specimen, but the 'graptolite' was most probably a fragment of carbonised wood, which is fairly widespread in the South Georgia strata. Ferguson and Gregory were encouraged in their identification by an equally erroneous report by (Pirie 1905) of a graptolite from the South Orkney Islands, the specimen having been collected during the 1902-1904 Scottish National Antarctic Expedition. Whilst at South Georgia, Ferguson received a number of rock specimens from the South Orkneys, and was struck by the apparent similarity of some lithologies to those of South Georgia (Notebook 2, 156-159, dated 28 March 1912); not shy of drawing broad conclusions, he favoured a correlation. Ferguson also drew comparison with the Falkland Islands, which he did not visit until the following year. Noting that the rocks there were known to be of Devonian age and at a relatively low metamorphic grade he concluded that the rocks of South Georgia were clearly older and "lie somewhere between the base of the Devonian and the base of the Cambrian System” (Salvesen Report, p. 55).

The 'graptolite' from the South Orkney Islands had been verified by no lesser authorities than Gertrude Elles and Ben Peach, the latter also identifying phyllocarid remains (Pirie 1905); Pirie’s paper was presented to the Royal Society of Edinburgh by John Horne. With such an imprimatur, the fossils were not unmasked (as most probably indeterminate plant material) for another 50 years, but not before another erroneous 'graptolite' discovery by Argentine geologists, as reported by Cordini (1955, 273-277) and Thomson (1977). When Pirie’s specimens (National Museum of Scotland specimen numbers 1954.2.28 and 29) were re-examined by the Birmingham University palaeontologist Dr Isles Strachan, he reported, as quoted by Adie (1957, p. 22): “The fragmentary specimens from the South Orkney Islands are extremely poorly preserved. No thecae can be seen on the supposed graptolite stipes and the markings on the other organic fragments can be explained in several ways. There is no positive 
evidence for an Ordovician-Silurian age for the shales although, of course, the specimens can be interpreted to agree with such an age. They could, however, equally well be identified as plant fragments and assigned to the Carboniferous.” Eventually, the supposedly graptolitic rocks yielded Triassic conodonts and radiolaria (Dalziel 1979; Dalziel et al. 1981).

The assumption of an Early Palaeozoic age for the South Georgia strata led Ferguson initially to dismiss the evidence of a Mesozoic age gathered by others. Indeed, with an Early Palaeozoic age assumed for the succession above Ferguson's putative unconformity, his notes and the first version of the geological cross-section of the island that he produced (Figure 6) assign an Archaean (Ferguson consistently uses Archean) age to the supposedly older rocks beneath the 'unconformity'. Even when he found a probable ammonite fossil at Prince Olav Harbour (Ferguson refers to this locality as 'Port Gladstone') (Figure 2), rather than consider a Mesozoic age, Ferguson instead noted (notebook 2, p. 75: 2 Mar 1912): "It is not an Ammonite but one of the ... Goniatites family, which may be early Devonian, and may also be Cambrian.” This may have been the same specimen referred to by Ferguson, when back in Glasgow, in a letter to Gregory dated 20 August 1913 that is now archived in the Hunterian Museum. By then Ferguson's anti-ammonite opinion had hardened and he wrote: “Then as to the discovery of an ammonite in Prince Olaf's Harbour [during Filchner's German expedition] ... I don't think it is an organism at all but a sort of ring marking due to lateral pressure which is markedly evident where the supposed fossil was got. I got a specimen from the very same spot which is now in the laboratory at the University.” We have not been able to locate a specimen answering this description, but it cannot have been definitive since there is no further mention of the fossil, either in Ferguson's formal report to the Salvesen Company on his work, or in the published description of Ferguson's South Georgia fossils by Gregory (1915). However, Gregory could not ignore the Mesozoic possibility once he had seen the ammonite collected by Filchner's German expedition (a more recently-observed example of a South Georgia ammonite is shown in Figure 7), and after Mesozoic radiolaria were identified in thin sections prepared from some of Ferguson's rock specimens. Gregory was hence forced to propose another, hypothetical unconformity within the sedimentary succession. This left the overall interpretation as a succession of Mesozoic strata unconformably overlying a Lower Palaeozoic succession of almost 
identical lithology; the Lower Palaeozoic strata in turn resting unconformably on even older, possibly Archaean strata but which were still of a similar lithology to the presumed younger rocks. In fairness to Gregory, he did consult widely on the nature of the South Georgia ‘fossils’ and the Hunterian Museum archive holds letters from Salomon and Heim (concerning material collected by the German expedition), Nordenskjöld (leader of the Swedish Antarctic Expedition), Hinde (a British authority on radiolaria), and Bassler (an eminent palaeontologist at the Smithsonian Institution, Washington). Extracts from their letters were quoted by Gregory in his 1915 assessment of South Georgia palaeontology.

\section{Influences and legacy}

Ferguson's assumptions on age and stratigraphy were soon challenged, as described above, and the entire South Georgia sedimentary succession is now regarded as Mesozoic, and most probably Lower Cretaceous. Fortunately, his assessment of the possibility of economic mineralisation was more realistic and his report to the Salvesen Company was largely negative. Even so, Ferguson could not resist a bold overview. He clearly saw vertical, fault-related movement as generally dominant and in South Georgia imagined that the central mountain range was underpinned by an intrusive igneous core, with major faults flanking the mountains and downthrowing the higher divisions of the sedimentary succession to either side (Figure 6). It was these putative faults that, he proposed in his report to Salvesens, might host mineralisation; despite that advice, Salvesens did not sponsor further prospecting. The structural interpretation was most probably influenced by the tuition Ferguson had received at Glasgow University from Professor J. W. Gregory. It is instructive to note the similarites between Ferguson's South Georgia cross-section (Figure 6) and the section across a 'block mountain' (Figure 8) that had been published by Gregory in his acclaimed account of the African Rift Valley (Gregory 1896, figure 10). The model was also in keeping with Gregory’s known preference for South Georgia to be a relic of a lost Atlantic landmass, the subsidence of which had been controlled by normal faulting (see discussion in the later section "Epilogue: the regional perspective”). Nevertheless, the moderating influences of Gregory and Tyrrell are perhaps evident in the changes that Ferguson made to his cross-section (Figure 6) as submitted in the report to Salvesen (the report is dated 15 July 1912 with the cross- 
section presumably drafted some time before) and as prepared for his published paper on South Georgia (where the cross-section is dated 5 July 1912). For that published version (Ferguson 1915, plate 82), the igneous core to the central mountain range and the reference to Archean (sic) rocks were both removed, and the fault pattern was modified; there is no mention of Archaean rocks in the published text. In contrast, Ferguson’s confidential report to Salvesen (perhaps not seen by Gregory) contains many references to the supposed Archaean rocks.

Despite the shortcomings of Ferguson's work on South Georgia his subsequent collaboration with Tyrrell led to a substantial body of petrographical work that has stood the test of time. Based on the specimens that Ferguson collected, specimens collected subsequently by whalers and sent back to Ferguson, and various other material collected both prior to Ferguson's visit and by later expeditions, Tyrrell produced a sequence of papers providing unrivalled petrographic detail. Macdonald et al. (1987) note that these led to Tyrrell (1930) producing one of the best of the early stratigraphical schemes for South Georgia, even though he never visited the island.

Ferguson left South Georgia in mid-April 1912. As noted above, his formal report presented to the Salvesen Company is dated 15 July 1912. His paper on the geology of the island (Ferguson 1915) was received by the Royal Society of Edinburgh on 2 March 1914. Its submission was probably organised by Gregory, since by then Ferguson had returned south on behalf of the Salvesen Company and was based in the Falkland Islands. Gregory read the paper before the Royal Society on 6 July 14, though by that time Ferguson was back in Glasgow. The place-name 'Ferguson Peak' (561 m) [5447’S 3550'W] was subsequently applied to a locality in the south-east of South Georgia following topographical surveys in the 1950s (Figure 9).

Ferguson and William Speirs Bruce

Before departing for South Georgia, Ferguson had sought the advice of William Speirs Bruce, leader of the 1902-1904 Scottish National Antarctic Expedition (SNAE) who on his return had established the Scottish Oceanographical Laboratory in Edinburgh. The two men corresponded and met on several occasions; 21 of Ferguson's letters to Bruce are preserved in the Scott Polar Research Institute, 
Cambridge (SPRI archive numbers MS 101/39/1-21). Bruce was supportive and provided Ferguson with relevant literature, including the Pirie (1905) paper on the supposed graptolites from the South Orkney Islands that was to prove so unfortunately influential. In return, Ferguson agreed to collect specimens, biological as well as geological, in South Georgia for Bruce’s laboratory museum, and Bruce loaned appropriate equipment to facilitate the field work.

The correspondence was renewed when Ferguson returned from South Georgia and was concerned with the identification and distribution of his geological specimens. Some specimens were clearly left in Edinburgh, with the Oceanographical Laboratory or the University geology department, but their fate is uncertain. Most of the specimens remained in Glasgow, and from one letter we learn that Pirie had visited Ferguson to see the putative South Georgia graptolite; elsewhere there seems to be agreement on a supposedly close geological correspondence between South Georgia and the South Orkney Islands. Then, in a letter dated 6 September 1913, Ferguson responds positively to a suggestion from Bruce that an account of the geology of South Georgia should be included in the 'Scotia' Reports, the volumes detailing the results of the SNAE that Bruce was then editing. Ferguson notes that Professor Gregory was in favour of such an inclusion, and proposes that he, Ferguson, should re-write an appropriate account of South Georgia's geology during his forthcoming voyage to the Falkland Islands. The next letter to Bruce was written from the Falklands, from Port Stanley and dated 15 November 1913. In it, Ferguson proposes a more ambitious scheme to incorporate the geology of the Falklands as well as that of South Georgia into the 'Scotia' Reports, but pointing out that further specimens needed to be acquired from the igneous complex at the south-east end of South Georgia (which Ferguson had not been able to visit) and that a scheme to obtain the necessary material was in hand. No further letters survive from this period of the correspondence and in the end no account of South Georgia's geology appeared in the 'Scotia' Reports, although the additional specimens were collected by Salvesen workers based on South Georgia, passed on to Ferguson, and ultimately described by Tyrrell (1916, 1918).

Although nothing came of the proposal to include Ferguson’s South Georgia work in the official 'Scotia' Reports of the SNAE, the established links between Ferguson and 
Bruce have led to some historical confusion. For example, in his comprehensive biography of Professor J. W. Gregory, Leake (2011) suggests that Gregory’s involvement with South Georgia arose from Ferguson's participation in the 19021904 SNAE (op. cit. p.146). As has been discussed above, this is demonstrably not the case. The SNAE expedition aboard the Scotia did not visit South Georgia, and Ferguson was not a member of that expedition (he was working in southern Africa in the 1901-1903 period). The SPRI archive correspondence makes it clear that Bruce and Ferguson did not meet until November 1911. It includes a letter of recommendation, dated 23 November 1911, written to Bruce on behalf of Ferguson by J. D. Falconer, a lecturer in geography at Glasgow University from 1911 to 1914.

\section{Falkland Islands}

Ferguson returned to the South Atlantic on behalf of the Salvesen Company for the 1913-1914 Austral summer, arriving in Stanley, Falkland Islands, on October $15^{\text {th }}$ and departing in mid-April. At the time, Salvesen operated a shore-based whaling station on New Island, in the far west of the Falklands archipelago; established in 1909 it lasted for only 6 years. Not all of his time was spent in the Falklands and from 1 December 1913 to 7 February 1914 Ferguson accompanied whaling vessels around the South Shetland Islands and the northernmost part of the Antarctic Peninsula. This was clearly the main focus of his investigations and the geological observations from this Antarctic excursion were published as a scientific paper (Ferguson 1921) in the Transactions of the Royal Society of Edinburgh, accompanied by a detailed description by Tyrrell (1921) of the specimens that he collected. No account of Ferguson's Falklands investigations was ever published, though his notebooks show that he made extensive observations and developed comprehensive, if somewhat idiosyncratic views on the regional geology. We suggest, and develop the idea below, that discussion of his findings with Gregory and Tyrrell led Ferguson to doubt his original conclusions on the geology of the Falkland Islands and dissuaded him from publishing.

The Falkland Islands lie in the South Atlantic Ocean approximately $650 \mathrm{~km}$ east of the Strait of Magellan, around latitude $52^{\circ}$ south, longitude $60^{\circ}$ west. The archipelago 
comprises two main islands, East Falkland and West Falkland, a dozen or so large subsidiary islands, and myriad smaller islands, rocks and reefs (Figure 10). These all add up to a total land area of just over $12000 \mathrm{~km}^{2}$. The topography is relatively subdued with the highest hills rising to about $700 \mathrm{~m}$. A comprehensive account of the geology is given by Aldiss \& Edwards (1999). The oldest rocks seen are the Proterozoic, ca 1000 million years old, granite and gneiss of the Cape Meredith Complex, which has a very small outcrop on the southernmost point of West Falkland. This 'basement' complex is unconformably overlain by the West Falkland Group, a thick succession of fluvial to neritic, clastic strata that is unequivocally Devonian in part but which may range in age from Silurian to Carboniferous. A younger division, the Lafonia Group, has a Permo-Carboniferous glacigenic tillite near its base and passes upwards into a thick succession of Permian deltaic strata. The metamorphic and sedimentary rocks are cut by a multitude of Jurassic and Cretaceous dolerite dykes. Durant \& Farrow (1999) record 16 'Ferguson’ specimens from the Falkland Islands in the Hunterian Museum collection; we can confirm that most are either fossiliferous Devonian sandstone from the West Falkland Group or clasts from the glacigenic tillite in the Lafonia Group.

Prior to Ferguson's arrival in the Falklands, specimens of bituminous oil shale had been found on several west-facing beaches and had attracted much attention.

Ferguson visited the sites, examined them and the surviving specimens in great detail, and concluded that the oil shale did not have a local provenance but had been washed in as flotsam. He rather favoured a source in Patagonia but acknowledged that cargo lost from a wrecked or passing ship was also a possibility; subsequent opinion at Glasgow University was that the oil shale might well have been Australian (Gregory, cited in a letter from Ferguson to Miss Ethel Currie, a member of staff at the Hunterian Museum, 7 June 1922). This material was the main focus of Ferguson's subsequent report to the Salvesen Company on economic possibilities, though he made clear his opinion that it was not indigenous to the islands. In a subsequent economic assessment of Falklands geology, Baker (1924) presented further information supporting an Australian provenance, and anecdotal evidence of Australian oil shale cargoes passing through Stanley. 
Ferguson was equally dismissive of specimens of base metal ore that had been found on the southernmost shoreline of Lafonia. In his notes Ferguson wrote (Notebook 3, pp 51-52, 15 Nov. 1913):

“They are Copper and Iron Pyrites and Galena [lead sulphide]. The Galena is coarsely crystalline and may contain Silver. It has also apparently some Zinc Blende in it. The Copper and Iron Pyrites is in a Quartz matrix, and carries in some of the pieces a little Galena. The Galena in one piece carries Copper Pyrites and all of it carries a little of it. The Copper and Iron Pyrites with a very little Galena in it and all in a Quartz matrix may contain if tested both Gold and Silver. The specimens were got on the beach at Bull Point, the S.W. point of the East Falklands on the South Coast of Lafonia. As this place has been the scene of quite a number of shipwrecks of vessels coming round Cape Horn, it is not unlikely that the ore was strewed on the beach from a wrecked ship and probably came from Chile or other known metalliferous country on the South American West Coast. It is highly unlikely that it came out of the flat lying Permo-Carboniferous rocks at Bull Point.” Ferguson's surmise about shipwrecks is almost certainly correct: for example, the 400 ton barque Horatia, travelling from Valparaiso to Swansea with a cargo of copper ore, was wrecked on Bull Point on 19 August 1860 (Southby-Tailyour 1985, p. 67).

When it came to the general, regional geology of the Falklands, Ferguson's interpretations were not so astute and from a modern perspective look a little strange. This is unexpected, since only a few years prior to his visit much geological work had been carried out by Johan Gunnar Andersson during the Swedish South Polar Expedition (1901-1903) and Thore Gustaf Halle during the Swedish Magellanic Expedition (1907-1908). These two scientists had correctly established the basic pattern and nature of the geological succession (Andersson 1907b; Halle 1911), but Ferguson seems to have deliberately taken issue with all of their findings, sometimes dismissing their earlier work quite contemptuously. During his travels, Ferguson had developed a very low opinion of Norwegians, who comprised most of the whaling workforce, and perhaps this antipathy coloured his judgement of the abilities of Scandinavians in general, including Swedish geologists. The following examples illustrate the main points of difference.

The stratigraphical succession. 
The older part of the Falkland Islands sedimentary succession (West Falkland Group) comprises a thick accumulation of quartzite, sandstone and mudstone. Ferguson was impressed by the extensive cliff sections around the southern coast and islands of West Falkland, writing (Notebook 3, p. 19, 19 Oct 1913):

“The white Sandstone Series occupies the coast line from sea level to summit, in every rock escarpment, from Port Stephens, past Weddell Island, Beaver Island, and on to New Island. Some of the escarpments are fine examples of bedded sandstones, and in size and extent are in picturesque grandeur, all as fine as any bedded escarpments to be seen elsewhere.”

Andersson and Halle had correctly established that there were two quartz-sandstone divisions separated by micaceous sandstone and mudstone containing fossil shells of Devonian age (ca 400 million years old). Ferguson disagreed, mistakenly conflating the two quartz-sandstone divisions into a single unit lying above (and so being younger than) the fossiliferous sandstone and mudstone. In the following extracts from his notes, Ferguson refers to the quartz-sandstone and quartzite units as 'white sandstone' and the fossiliferous unit as 'shales and sandy shales'.

"The shales and sandy shales containing the Devonian fossils are [at Fox Bay] clearly and unmistakably below the white Sandstone Series”, (Notebook 3, pp 9-10, 19 Oct 1913). This is a correct interpretation of the Fox Bay locality.

"Cape Meredith ... shows us the fundamental error that Professor Andersson of the Nordenskjöld Antarctic Expedition had fallen into in describing the unconformability there. He makes the white Sandstone Series at Cape Meredith a lower series of the Devonian Sandstones on which overlie the shales, sandy shales etc of Fox Bay ... The white Sandstone Series above the fossiliferous shales etc. at Fox Bay ... is the one and only Sandstone Series in the West Falklands, and is clearly that at Cape Meredith. A mere walk over the ground from Fox Bay to Cape Meredith, or a cruise round the coast between the two points cannot fail to establish this plain and simple fact to any observer ... no lower horizon than the fossiliferous shales etc is to be seen in the West Falklands, or the East Falklands.” (Notebook 3, pp 14-16, 19 Oct 1913) 
Despite the emphatic tone of Ferguson's interpretation, he was entirely wrong. The Andersson-Halle version has proved to be correct.

\section{The glacigenic tillite beds}

One of Halle's most significant geological insights was the first recognition that the boulder conglomerate beds exposed at Hill Cove and elsewhere had been deposited from an ice sheet. The conglomerate contains a wide range of boulder lithologies, including granite and metamorphic rocks, and Halle realised that it was a local representative of the glacigenic tillite deposited widely across the southern continents during an ice age about 300 million years ago, when they were combined into the huge landmass of Gondwana. As such, the Falklands example (now known as the Fitzroy Tillite Formtion) is the direct equivalent of the Dwyka Tillite of South Africa. Halle's interpretation has been proved correct, but Ferguson thought it laughable, preferring instead to see the Hill Cove boulder conglomerate as a vestige of a very recent deposit that had once filled a valley eroded into a granite body now hidden beneath Byron Sound (Figure 11). His opinion is made very clear in the following extracts from his notes.

“This deposit stated by Halle to belong to the Glacial period of the Dwyka conglomerate in the Permo-Carboniferous rocks of South Africa ... is a bedded clay ... and contains boulders of Granite and other eruptive rocks, as well as boulders of sandstone, similar to the white Sandstone "in situ" adjacent to them ... The deposit has as much relationship to the striated glacial deposit of the Dwyka Conglomerate of South Africa, as it has to the Devonian white Sandstone Series, into which it is deposited and in places overlies. There is not the slightest sign of glaciation or icescratching to be seen in a single boulder along the whole length of the deposit.” (Notebook 3, pp 40-41, 7 Nov. 1913)

“The Soft Sandy Shale and Boulder deposit, is not a Glacial deposit. There is no single shred of evidence either in the soft sandy shale, and the boulders, occurring in it to show that it is a glacial deposit. How or why it should be connected with the Dwyka Conglomerate and the glacial deposit of Permo-Carboniferous age in South Africa is far from evident. ... To assert that it is the Dwyka Conglomerate is simply a 
wild absurdity. The latter is a hard indurated deposit of Palaeozoic age, the Hill Cove deposit, is a recent Quaternary deposit.” (Notebook 3, pp 163-164, 21 Mar. 1914)

“The assertion made by Halle ... shows the danger of advancing opinions with impeachable evidence to support them and indulging in the luxury of a mere theory." (Notebook 3, p. 164, 21 Mar. 1914)

The final statement above was particularly unfortunate since it is Ferguson himself who proves to have committed the crime with which he charges others, speculating, wrongly, that the submarine outcrop immediately offshore Hill Cove was of basement rocks like those seen at Cape Meredith. His disdainful dismissal of the glacigenic interpretation is particularly hard to understand since he was clearly familiar with the detail of Halle's published work, in which are reproduced photographs of icescratched boulders at Hill Cove. It is very likely that when back in Glasgow, and discussing his results with Gregory and Tyrrell, the true nature of the rock was pointed out to him. In the Hunterian Museum collection a microscope slide (TS4630) made from one of Ferguson's Hill Cove specimens, almost certainly for Gregory, is clearly labelled (in Tyrrell’s handwriting) 'Tillite (Permo-Carb = Dwyka of South Africa)'.

\section{Geological structure}

In East Falkland, the topographical contrast between the rocky upland of the Wickham Heights and the flat plain of Lafonia reflects the different geological structure underlying the two areas. Ferguson commented on that difference as follows:

"This fundamental change could only be produced by a structural fault, which undoubtedly exists between the ... line of the Wickham Heights and Mount Usborne, and the flat easy dipping rocks of the low, gently undulating country, stretching S. of its foothills to Darwen (sic) and over the length and breadth of Lafonia.” (Notebook 3, p. 128, 10 Mar 1914) 
“The Great Fault runs as near as we can see from the W. point of the N.W. Island standing out in the Falkland Sound, from the headland of Port Sussex, to a point about a mile S. of the head of Port Sussex, thence S.S.E. to a point about a mile S. of Ceritos, and about three miles S. of the crest of Mount Usborne. From this point it runs first a little S. of E. to a little below Mount Pleasant, then E. to Port Pleasant and Pleasant Island where it reaches the open sea. All to the North of the Great Fault is of Devonian Age, and all the rocks to the South of it, all of Permo-Carboniferous age.” (Notebook 3, p. 134, 10 Mar. 1914)

"The difference of the two types of scenery is so strongly marked, that we can tell with considerable precision, where the Permo-Carboniferous rocks begin and the Devonian rocks are cut off. “ (Notebook 3, p. 140, 12 Mar. 1914)

Ferguson sketched his view of the structure (Figure 12) but there is no 'Great Fault' and Ferguson's misinterpretation arose at least partly from his rejection of a glacigenic origin for the tillite. Halle had recognised this lithology at Port Sussex, but it was on the 'wrong' side of Ferguson's major fault. Of course, this posed no difficulty for Ferguson who dismissed the entire notion of the glacigenic unit being present. It was unfortunate that he was encouraged in this error by misinformation claiming the presence of Devonian fossils at Port Sussex that had appeared in an account of the 1872-1876 Challenger Expedition. Ferguson was aware of the report and noted:

"Halle and Scottsberg, draw the line of division, N. of Port Sussex and include the black fissile shales, and the White Sandstone overlying it in the Permo-Carboniferous beds. They make no reference to faulting, and leave it to be inferred that the line of separation may be an unconformity. That these black shales and the White Sandstone are not related to the Permo-Carboniferous rocks, we can quote Sir Wyville Thomson of the Challenger Expedition, in his book “The Atlantic” Vol 2 page 208 - 1877. He states that "while the ship H.M.S. Challenger was at Port Stanley, Mr Moseley went across to Port Sussex, to examine a supposed deposit of coal, and brought back a fine lot of fossils from the Sandstone.” (Notebook 3, p. 131, 10 Mar. 1914)

Unfortunately, Sir Wyville Thomson (scientific leader of the Challenger Expedition and Professor of Natural History at Edinburgh University) had confused the issue. 
The fossils in question came not from Port Sussex but from Port Louis, as made clear in the formal scientific description by Etheridge (1885). This contradiction may later have been pointed out to Ferguson by his better informed mentors at Glasgow University.

In fact, the relatively abrupt topographical transition seen across East Falkland coincides with a structural mountain front: a south-directed fold and thrust belt lies to the north, culminating in the Wickham Heights, with a foreland basin developed ahead of the mountain front and now forming Lafonia. Curiously, Ferguson debates the possibility of south-directed thrusting, but dismisses it as follows:

“The folding and crumpling in the Devonian Sandstones cannot be traced to any intrusive thrust movement acting from the North of the Falklands. If it had we should have expected to see the crumpling and folding, most strongly in evidence along the North coast. It is less disturbed along the North coast than along the line of the ... Wickham Heights... South of this main line of folding or crumpling in the West Falklands, there is an abrupt change to flat or gently dipping rocks of the White Sandstone Series. A great thrust movement from the N. would have effected a folding and crumpling result, that would not have died out suddenly but very gradually.” (Notebook 3, p. 201-202, 10-15 Apr 1914)

There is evident confusion here between the very different structural styles seen in East and West Falkland, but the fundamental issue is Ferguson's conviction that vertical faulting is the dominant process. Hence he developed a structural model that explained all folding as a consequence of faulting interacting with a pre-existing basement topography, as exemplified in the following two quotations from his unpublished notes, there are many other similar statements:

"The folding and crumpling is here probably due to concealed internal cores of Granite or Mica-Schist, which have been subjected to differential movement. Movements of that kind, in a hard Plutonic or Metamorphic rock body, with an irregular outline, is sure to wedge in the softer sediments, which mantle them and result in folding and a varying intensity of crumpling action.” (Notebook 3, p. 176, 24 Mar 1914) 
"The folding and crumpling and faulting can all be explained by the presence and existence of ridges and old land surfaces in valleys, being formed of Plutonic or Metamorphic rocks.” (Notebook 3, p. 202, 10-15 Apr 1914)

\section{South Shetland Islands and Graham Land}

From the Falkland Islands, Ferguson embarked on a 10-week prospecting voyage (December 1913 to February 1914) around the South Shetland Islands and adjacent coasts of the Antarctic Peninsula. During his voyage to the Falklands and subsequent trips around the archipelago Ferguson had developed doubts as to the seaworthiness and abilities of the whaling ships and their crews. So concerned was he about the outlook for his voyage from the Falklands to the South Shetland Islands, that he wrote to his MP, Sir Robert Balfour (Partick Division, Glasgow) asking that, should he not return, the circumstances should be made known to the relevant aurthorities, his family and executors. Fortunately however, things seem to have improved for him and prior to departure for the South Shetlands Ferguson felt able to record, in his typically self-possessed style, that:

"I have created a healthy discipline among the crew of the SS Hanka and the manager of the New Island Station, which promises to work well during the prospecting trip in the South Shetlands.” (Notebook 3, p. 71, 30 Nov. 1913)

In the event, the Antarctic work was completed successfully. A different approach was required to that adopted for South Georgia and the Falklands in that the localities visited were relatively isolated from each other across a wide area of the South Shetland Islands and the Gerlache Strait area of Graham Land (the northern end of the Antarctic Peninsula). His landings were opportunistic, depending on weather and seaice conditions, and were limited to the relatively few safe anchorages known to the whalers. In contrast to South Georgia and the Falkland islands, much of the rock exposed was igneous, some being the products of very recent volcanism. Ferguson published an account of his work in the region (Ferguson 1921) and his findings have been summarised by Smellie et al. (1984, 3-6) as follows: 
“The greater part of [Ferguson's] work in the South Shetland Islands relates to King George Island, where he distinguished an earlier (? Middle Jurassic) sequence of stratified sediments with interbedded lavas from later (Cenozoic) basalts and andesites. Dioritic intrusions, which had altered the earlier sequence and caused extensive quartz-pyrite mineralization in some areas (notably Esther Harbour), were also noted. Despite Ferguson's emphasis on the high proportion of sedimentary rocks in the older sequence, Tyrrell's (1921) petrographical account showed that they figured insignificantly in his collections. He also made no petrological distinction between the two main sets of lavas, but described them as dominantly andesitic types (including bandaite) with rarer more acidic ones. However, he recognised that the basaltic rocks, then known from Bridgeman and Deception islands, and also Edinburgh Hill, Livingston Island, constituted a third and more recent phase of volcanic activity.”

The place-name 'Edinburgh Hill’ (Figure 13) was first applied by Ferguson in his 1921 paper but was clearly a second choice. In his report to the Salvesen Company (pp 18-19) Ferguson described Edinburgh Hill as follows:

"In the Macfarlane Strait separating Livingstone Island from Greenwich Island, but lying close to the N.E. shoreline of Livingstone Island, there is a volcanic neck forming a little rock island or peninsula, a beautiful specimen of Columnar Basalt and rising 500 to 600 feet above sea level ... This little hill we have named Staffa on account of its similarity to the columnar island containing Fingal's Cave, on the west coast of Scotland.”

In common with Staffa and despite its shape, Edinburgh Hill would seem more likely to be a remnant of an eroded lava sheet rather than an intrusive volcanic neck.

The geological accounts by Ferguson and Tyrrell are readily reconciled with current interpretations, although much of Ferguson's supposedly Jurassic volcanic succession was later proved to be Cenozoic (Davies 1982). It is a curious contrariety that in advocating a Jurassic age for some of the South Shetlands rocks, Ferguson cited the discovery in Graham Land by the Swedish South Polar Expedition (1901-1903) of a Jurassic flora in strata subjacent to an extensive spread of volcanic rocks (Andersson 1907). It was the same expedition's geologist - Johan Gunnar Andersson - whose work in the Falkland Islands he had so roundly disparaged and whose Mesozoic fossil 
discovery in South Georgia he had dismissed. During the Swedish Expedition Andersson had preceded Ferguson to the South Shetland Islands, but the specimens collected during his relatively brief visit were lost when the expedition's ship was crushed by pack ice and sank.

Jurassic volcanic rocks proved widespread in parts of Graham Land, forming what became known as the Upper Jurassic Volcanic Group in the influential interpretation of the Antarctic Peninsula's regional geology and stratigraphy presented in a series of papers by R. J. Adie and summarised in Adie (1964). Ferguson's South Shetlands stratigraphy, albeit erroneous in part, most probably informed Adie's interpretation, in which he extended his Upper Jurassic Volcanic Group to incorporate the supposedly Jurassic lavas of King George Island, with a more tentative correlation to an 'Older Volcanic Group’ in Livingston Island. In respect of Ferguson’s work in Graham Land, though rather overlooking the economic aspects, Adie (1964, p 140) noted only that “[s]ome sectors of the Danco Coast were prospected by Ferguson in 1913-14 while employed by Chr. Salvesen \& Co. of Leith. He confirmed many of the earlier field observations in this area and collected quantities of specimens which were later described by Tyrrell.”

Despite his work's stratigraphical shortcomings, from the prospecting viewpoint Ferguson achieved some success in that he was able to return with metal sulphide-rich specimens from several localities. When back in the Falklands he attempted some analytical work and was disappointed to confirm the suspected absence of copper in some of the pyrite-rich ores. Though subsequent analytical work back in Scotland did show that some specimens were of ore grade, Ferguson was realistic in his assessment. His report to the Salvesen Company emphasises the restricted nature of the ore-grade bodies, and the immense practical difficulties of working them. Nevertheless, interest was maintained, and surviving letters from Ferguson in the Salvesen Archive show that there was still discussion of the possibilities as late as 1931, though there is no evidence of any serious intent on the part of the Salvesen Company.

It would seem that Ferguson regarded his Antarctic results as being of particular importance since he ensured the wide distribution of duplicate sample sets. The main 
collection was donated by the Salvesen Company to Glasgow University’s Hunterian Museum in 1915; Durant \& Farrow (1999) record 210 'Ferguson' specimens therein from the South Shetland Island and the adjacent parts of Graham Land. In addition, representative suites of specimens were sent to "the Natural History Museum, South Kensington, the Royal Scottish Museum, Edinburgh and the Sedgwick Museum, Cambridge” (Ferguson 1921). All of these collections are extant though the sulphiderich specimens have crumbled: as accurately as could be ascertained, The Natural History Museum (London) holds 175 specimens, the National Museum of Scotland (Edinburgh) holds 182 specimens, the Sedgwick Museum (Cambridge) holds 53 specimens.

Ferguson's experiences in the Antarctic also led to further correspondence with W. S. Bruce. Four letters written by Ferguson to Bruce during March 1918 (SPRI Archive) discuss the geography and toponymy of Livingston and Trinity islands - and include some negotiations as to which features should be named 'Bruce' and which 'Ferguson' on maps that Ferguson was preparing of locations a little farther south.

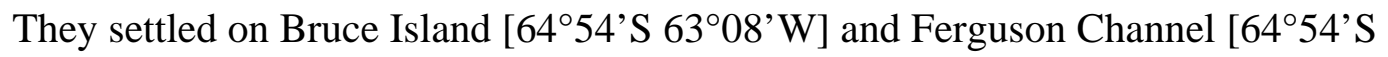
$\left.63^{\circ} 00^{\prime} \mathrm{W}\right]$, both adjacent to Bryde Island off the Danco Coast, north-west Graham Land. At the time Bruce was clearly compiling geographical information on the region and, at his request, Ferguson sent him descriptions of the various anchorages that had been used during the 1913-1914 prospecting trip.

\section{Epilogue: the regional perspective}

Ferguson's large-scale interpretations of the regional geology of the South Atlantic areas that he visited were all driven by a focus on vertical fault movements as the primary tectonic process. Even his interpretation of South Georgia's geology was dominated by faulting, despite the obvious and widespread appearance of large, overturned folds. This predilection can probably be traced back to the influence of Gregory, who had a long-standing interest in the region. As early as 1901, in a discussion of the objectives of the National Antarctic Expedition, he had illustrated a continuation of the Andes into the Antarctic Peninsula via an eastward-closing loop, admittedly one that closed far to the west of South Georgia (Gregory 1901). In this he followed Arçtowski (1895) who had put forward the hypothesis that "the Andes are to 
be seen again in Graham Land”. At the time he wrote, Gregory had anticipated leading the National Antarctic Expedition's science programme, but in the event he did not take part and the 1901-1904 Discovery expedition was led by Robert Scott, with Edward Wilson as chief scientist. The suggestion that the Andes continued southwards to Graham Land via an eastward, horseshoe-shaped bend was then discussed in some detail by Eduard Suess (1909, 488-497). One possibility that he considered was that a submerged geological link followed the Scotia Arc, a submarine feature defined by soundings taken during the SNAE and named after the Scotia, the expedition’s ship (Bruce 1905). The Scotia Arc extends through South Georgia, around the South Sandwich Islands and on into the South Orkney Islands (Figure 1) but Suess, whilst supporting the broad idea, felt it more likely that the eastward bend closed to the west of these islands, linking Burdwood Bank with Elephant Island and the South Shetlands. This left the more easterly, poorly known islands as geological enigmas. Suess had also noted the anomalous geology of the Falkland Islands, describing the archipelago as an "alien and divergent fragment”.

An alternative hypothesis, probably favoured by Gregory, regarded the Falkland Islands, South Georgia and the South Orkney Islands as vestiges of a foundered continental block that had once occupied the South Atlantic region. In general, Gregory supported the view that the ocean basins were created by the fault-controlled subsidence of continental areas, but though he was certainly influential in delaying acceptance of Wegener's (1912, 1915) formulation of continental drift, Leake (2011, 187-191) suggests that Gregory’s position on the subject was in fact rather ambivalent. Indeed, Gregory’s review of the first English translation of Wegener's book, by then in its $3^{\text {rd }}$ German edition (Gregory 1925) was broadly supportive, noting that “[ $t$ ]he favourable reception of Prof. Wegener's theory is significant of marked changes of opinion as regards the structure and history of the earth. It shows that the once widely adopted view that oceans and continents have always been in their present positions no longer hampers geological interpretation, and it marks the growing belief in the effective mobility of the earth's crust.” In the United States of America, where continental drift was almost universally dismissed as absurd, Gregory was actually perceived as somewhat pro-Wegener (Oreskes 1999, 124-126). However the putative, if ultimately erroneous, evidence for early Palaeozoic rocks on South Georgia encouraged interpretations of the island as forming a relic of a foundered 
continent, and Gregory's palaeontology was certainly instrumental in fostering that view.

Nevertheless, in his assessment of Ferguson’s South Georgia work, Gregory (1915, p. 822) felt that the evidence presented was insufficient to determine whether the island formed part of the "mountain loop that must once have connected Patagonia [South America] with Graham Land [Antarctic Peninsula]”, or whether that 'loop' passed west of the island leaving South Georgia as the vestige of a foundered Atlantic continent, 'Flabellites-Land’ as it had been designated by Schwarz (1910, p. 159) based on the distribution of a small Devonian brachiopod then known as Leptocoelia flabellites. The genus Leptocoelia is now restricted to North America and associated forms from South America, the Falkland Islands and South Africa are assigned to Australocoelia palmata. Tyrrell (1915), in his description of the petrography of Ferguson's South Georgia specimens that accompanied the papers by Ferguson and Gregory, stressed their similarity to rocks from the South Orkney Islands, but was equally non-commital with regard to the overall regional structure. However, after reviewing the subsequently collected specimen suites, Tyrrell (1918) came down against Suess's 'great loop', preferring that “South Georgia and the South Orkneys are remnants of an ancient continental land which once occupied the South Atlantic”. Such thinking carried through to Gregory's (1929) presidential address to the Geological Society of London, wherein he included South Georgia within a Devonian 'Flabellites Land' and both South Georgia and the Falkland Islands within a late Palaeozoic 'Gondwanaland' that included the entire area of the South Atlantic Ocean (Figure 14). Clearly Gregory was not convinced by Du Toit’s (1927, 102-103 \& figure 7) reconstruction in which the South Atlantic was eliminated and geological links between Africa and South America were emphasised; the Falkland Islands were notably moved a considerable distance north to align their geology with the structural trends seen in the two, now contiguous continents. Gregory's doubts arose from his realisation that if the Atlantic Ocean was once narrower, then the Pacific Ocean must once have been wider. Leake (2011, p. 187) has pointed out that this result conflicted with Gregory's assessments of trans-Pacific floral and faunal distributions, and was one of the principal difficulties identified by Gregory in Wegener’s ‘displacement hypothesis'. 
When working in South Georgia, and before visiting the Falkland Islands, Ferguson had speculatively assumed that there would be some geological connection between the two. When this proved not to be the case Ferguson mused, in his unpublished notes, on a South American connection for the Falklands. He envisaged the islands as an emergent, south-eastern part of the rim of an enormous basin of tectonic subsidence, the rim, underpinned by plutonic rocks, extending westward to Tierra del Fuego and the Andes, and northwards to Uruguay. The Devonian strata seen in the Falklands were part of the succession deposited in this basin, which extended to underlie, at depth, much of Argentine Patagonia. Strangely, this proposal was markedly at odds with his acceptance elsewhere of the close stratigraphical link between the Falklands and South Africa, his rejection of the tillite notwithstanding. Such conjectures may now seem outlandish but were presumably thought reasonable in terms of ocean formation by the fault-controlled disruption and subsidence of continents, the process then favoured by Gregory. Nevertheless, Ferguson's suggestion may have been a little too radical even for Gregory, and the idea was not pursued. It may also have emphasised the mismatches, partly noted by Durant \& Farrow (1999), between the various ‘continental foundering' models: the Falklands and South Georgia had been variously identified as the southern limit of Gregory's Flabellites Land, the northern limit of Tyrrell's South Atlantic landmass, and the eastern limit of Ferguson’s ‘Greater Patagonia’.

In conclusion, whilst it must be admitted that many of Ferguson's geological interpretations were erroneous, they were very much of their time and were certainly influenced by Gregory, his mentor at Glasgow University and one of the most eminent geologists of the day. In common with Pirie and many others before them, both men were precipitant in extrapolating from their experiences of Scottish lithologies and structures into their interpretations of geology in very different settings. So, for example, deformed and cleaved sedimentary successions were regarded, a priori, as Lower Palaeozoic, with any evidence to the contrary viewed with great suspicion. This was not an unknown problem. It is salutary to remember that the very same issue had been identified long before, in a similar part of the world, by Charles Darwin (1846, p. 152) when writing on the geology of Tierra del Fuego which he had visited aboard HMS Beagle: "The great clay-slate formation of Tierra del Fuego being Cretaceous ... which, without the evidence afforded by the fossils, 
would from the analogy of most known districts, probably have been considered as belonging to the Palaeozoic series.” The ‘clay-slate’ of Tierra del Fuego is broadly analogous to the South Georgia succession.

Setting aside the misconceived structural-stratigraphical interpretations, in terms of his own speciality of mineral prospecting, Ferguson's assessments, though largely negative, were accurate enough and this aspect of geology was after all the primary purpose of his expeditions. These were notable for being amongst the earliest examples of private, commercial enterprise being brought to bear on terrestrial Antarctic exploration. Ferguson's field-work added a little to the slowly accumulating knowledge of geology in the South Atlantic region, but perhaps his most substantial contribution arose through the provision of well-documented specimens that were subsequently described petrographically by Tyrrell. In a series of papers, Tyrrell gave accurate and comprehensive descriptions of Ferguson's rock specimens from South Georgia, the South Orkney Islands, and the South Shetland Islands and adjacent parts of the Antarctic Peninsula (though not from the Falklands). His expertise thus demonstrated, Tyrrell subsequently attracted other collaborators, many listed by Durant \& Farrow (1999), and it is he whose contribution to the region's geology is remembered, despite the fact that he never visited the sources of the rocks that he described. Conversely, Ferguson, who actually suffered the tribulation and privation of early $20^{\text {th }}$ century Antarctic fieldwork is largely forgotten.

After his expeditions to the South Atlantic region, Ferguson continued with his itinerant prospecting and mine surveying activities, though he may have suffered some after-effects from exposure to Antarctic weather conditions aboard a small whale-catcher. Writing to Miss Currie of the Hunterian Museum (where the letter is archived) on 7 June 1922 he complains about 'lumbago, muscular rheumatism and old age' in a letter accompanying a specimen of the Falkland Islands oil shale. This letter affords very rare evidence that Ferguson might have had a somewhat ironic sense of humour as he wrote of the oil shale: "Eight years ago in the Falklands when I first saw it, I had visions of a steady stream of golden shekels pouring into my banking account from it, but a little later I was cursing it for raising false hopes.” 
Nevertheless, despite the lumbago and rheumatism, in the following year Ferguson spent time in Canada, writing again to Miss Currie in September 1923 with a specimen of oil shale from New Brunswick accompanying the letter. Fragmentary notes from 1924 and 1925 then suggest involvement with mine surveys in the Lancashire and Ayrshire coalfields. At some point Ferguson also worked on English clays, including 'Devonshire Ball Clay’ and clays derived from the Dartmoor Granite, whilst a letter written to Mr Theo Salvesen on 18 July 1930 (and now held in the Salvesen Archive, Edinburgh University Library) notes that he “... had been away for a good time prospecting for aluminous ores for a chemical company”. The letter to Theo Salvesen discusses the economic prospects for some of Ferguson's discoveries in the South Shetland Islands, demonstrating his continuing interest in the Antarctic. However, by that time the lumbago and rheumatism may have been recurring, since the letter was written from the Waverley Hydropathic Hotel, Melrose. David Ferguson died in Glasgow on 8 March 1936 aged about 79.

\section{Acknowledgements}

We are extremely grateful to Vera Harvey, who painstakingly and accurately transcribed David Ferguson's notebooks, and to staff at the University of Glasgow Archive Services where they are held. Thanks are also due to Tricia Boyd and colleagues at the University of Edinburgh Library’s Special Research Collection for assistance in accessing the Salvesen Archive, and to Naomi Boneham of the Scott Polar Research Institute, Cambridge, and Vicki Hammond of The Royal Society of Edinburgh, for assistance in locating archive material held by those organisations. Access to Ferguson’s ‘duplicate’ specimen collections was facilitated by Peter Tandy at The Natural History Museum, London, Dan Pemberton at the Sedgwick Museum, Cambridge, and Simon Howard at the National Museum of Scotland, Edinburgh. Craig Woodward and Brian McIntyre, British Geological Survey, Edinburgh, assisted in the preparation of illustrations. Helpful reviews by Simon Flower (British Geological Survey) and the two referees, John Smellie (University of Leicester) and Mike Thomson (University of Leeds), are gratefully acknowledged. PS publishes by permission of the Executive Director, British Geological Survey (NERC).

\section{References}


Adie, R. J. 1957. The petrology of Graham Land: III. Metamorphic rocks of the Trinity Peninsula Series. Falkland Islands Dependencies Survey Scientific Report, 20, $26 \mathrm{pp}+2$ plates.

Adie, R. J. 1964. Geological History. In: Priestley, R. \& Robin, G. de Q. (eds) Antarctic Research. Butterworths, London. 118-162.

Aldiss, D. T. \& Edwards, E. J. 1999. The Geology of the Falkland Islands. British Geological Survey Technical Report, WC/99/10.

Andersson, J. G. 1907a. On the principal results of the Swedish Antarctic Expedition. Compte Rendu 10ème Congrès géologique international, Mexico 1906, 10. 723-733.

Andersson, J.G. 1907b. Contributions to the geology of the Falkland Islands. Wissenschaftliche Ergebnisse der schwedischen Südpolar-expedition 1901-1903, 3, Lieferung 2, $38 \mathrm{pp}$.

Arçtowski, H. 1895. Observations sur l'intérêt que présente l'exploration géologique des Terres Australes. Bulletin Société géologique de France. $3^{\mathrm{e}}$ série, 23, 589-591.

Baker, H. A. 1924. Final Report on Geological Investigations in the Falkland Islands, 1920-1922. Government Printer, Stanley. 38 pp, map, cross-section and 18 figures.

Bruce, W. S. 1905. Bathymetric Survey of the South Atlantic Ocean and Weddell Sea. Scottish Geographical Magazine, 21, 402-412 + 2 maps.

Cordini, I. R. 1955. Contribución al conocimiento del sector Antártico Argentine. Publicaciónes del Instituto Antártico Argentino, 1. 277 pp.

Curtis, M. L. 2011. Geological Map of South Georgia (1:250 000 scale). BAS GEOMAP 2 Series, Sheet 4, British Antarctic Survey, Cambridge, UK. 
Dalziel, I. W. D. 1979. The mythical graptolites of the South Orkney Islands. The Edinburgh Geologist, 6, 2-9.

Dalziel, I. W. D., Elliot, D. H., Jones, D. L., Thomson, J. W., Thomson, M. R. A., Wells, N. A. \& Zinsmeister, W. J. 1981. The geological significance of some Triassic microfossils from the South Orkney Islands, Scotia Ridge. Geological Magazine, 118, $15-25$.

Darwin, C. R. 1846. Geological Observations on South America. Being the Third Part of the Geology of the Voyage of the Beagle. Smith, Elder \& Co., London. 279 pp.

Davies, R. E. S. 1982. The geology of the Marian Cove area, King George Island, and a Tertiary age for its supposed Jurassic volcanic rocks. British Antarctic Survey Bulletin, 51, 151-165.

Douglas, G. V. 1930. Topography and geology of South Georgia. British Museum (Natural History) Report on the Geological Collections made during the voyage of the "Quest" on the Shackleton-Rowett Expedition to the South Atlantic \& Weddell Sea in 1921-22. Trustees of the British Museum, London. 4-24.

Du Toit, A. L. 1927. A geological comparison of South America and South Africa (with a palaeontological contribution by F. R. Cowper Reed). Carnegie Institution of Washington, Washington. 158 pp + 16 plates \& folded map insert.

Durant, G. P. \& Farrow, G. E. 1999. On the rocks in Southern and Atlantic Oceans changing geological perspectives. Scottish Naturalist, 111, 267-309.

Etheridge, R. 1885. Notes on the fossils collected by the Expedition. Report on the scientific results of the voyage of H.M.S. Challenger during the years 1873-76. Narrative 1 ( $2^{\text {nd }}$ Part), Published by Order of Her Majesty’s Government, 892-894.

Ferguson, D. 1915. Geological observations in South Georgia. Transactions of the Royal Society of Edinburgh, 50, 797-814 + 10 plates. 
Ferguson, D. 1921. Geological observations in the South Shetland Islands, the Palmer Archipelago and Graham Land, Antarctica. Transactions of the Royal Society of Edinburgh, 53, 29-55.

Ferguson, D., Tyrrell, G. W. and Gregory, J. W. 1914. The Geology of South Georgia. Geological Magazine, Decade 6, 1, 53-75.

Gregory, J. W. 1896. The Great Rift Valley. John Murray, London. 422 pp.

Gregory, J. W. 1901. The work of the National Antarctic Expedition. Nature, 63, 609612.

Gregory, J. W. 1915. The Geological Relations and Some Fossils of South Georgia. Transactions of the Royal Society of Edinburgh, 50, 817-822 + 2 plates.

Gregory, J. W. 1925. Continental drift. Review of The Origin of Continents and Oceans by Alfred Wegener. Translated from the 3rd German edition by J. G. A. Skerl. Nature, 115, 255-257.

Gregory, J. W. 1929. The Geological History of the Atlantic Ocean. Quarterly Journal of the Geological Society, London, 85, Proceedings lxviii-cxxii.

Halle, T. G. 1911. On the geological structure and history of the Falkland Islands. Bulletin of the Geological Institution of the University of Uppsala, 11, 115-229.

Hunter-Christie, E. W. 1951. The Antarctic Problem. George Allen \& Unwin, London. 336 pp.

Leake, B. E. 2011. The Life and Work of Professor J. W. Gregory FRS (1864-1932):

Geologist, Writer and Explorer. Geological Society, London, Memoirs, 34, 234 pp.

Macdonald, D. I. M., Storey, B. C. and Thomson, J. W. 1987. South Georgia. BAS GEOMAP Series, Sheet 1, 1:250 000, Geological map and supplementary text, 63 pp. Cambridge, British Antarctic Survey. 
Oreskes, N. 1999. The Rejection of Continental Drift. Oxford University Press, New York and Oxford, xi + 420 pp.

Pirie, J. H. H. 1905. On the Graptolite-bearing Rocks of the South Orkneys. Proceedings of the Royal Society of Edinburgh, 25, 463-470.

Schwarz, E. H. L. 1910. Causal Geology. Blackie, London. 248 pp.

Smellie, J. L., Pankhurst, R. J., Thomson, M. R. A. \& Davies, R. E. S. 1984. The Geology of the South Shetland Islands: VI. Stratigraphy, Geochemistry and Evolution. British Antarctic Survey Scientific Reports, 87, 85 pp.

Southby-Tailyour, E. 1985. Falkland Islands Shores. Conway Maritime Press, London. 270 pp.

Stone, P. 1980. The Geology of South Georgia: IV. Barff Peninsula and Royal Bay areas. British Antarctic Survey Scientific Reports, 96, 45 pp + 8 plates.

Suess, E. 1909. The Face of the Earth. (English translation by H. B. C. Sollas of Das Antlitz der Erde), 4. The Clarendon Press, Oxford. 673 pp.

Thomson, M. R. A. 1977. An annotated bibliography of the paleontology of Lesser Antarctica and the Scotia Ridge. New Zealand Journal of Geology and Geophysics, 20, 865-904.

Thurach, H. 1890. Geognostische Bechriebung der Insel Süd-Georgien. Die Internationale Polarforschung 1882-1883. Die deutschen Expeditionen und ihre Ergebnisse. 2: Beschreibende Naturwissenschaften in einzelnen Abhandlung. Hamburg. 107-164.

Turney, C. 2012. 1912 - The Year the World Discovered Antarctica. Bodley Head, London. 358 pp. 
Tyrrell, G. W. 1915. The Petrology of South Georgia. Transactions of the Royal Society of Edinburgh, 50, 823-836 + 1 plate.

Tyrrell, G. W. 1916. Further notes on the petrography of South Georgia. Geological Magazine, Decade 6, 3, 435-441.

Tyrrell, G. W. 1918. Additional notes on the petrography of South Georgia.

Geological Magazine, Decade 6, 5, 483-489.

Tyrrell, G. W. 1921. A contribution to the petrography of the South Shetland Islands, the Palmer Archipelago and the Danco Coast, Graham Land, Antarctica. Transactions of the Royal Society of Edinburgh, 53, 57-79.

Tyrrell, G. W. 1930. The petrography and geology of South Georgia. British Museum (Natural History) Report on the Geological Collections made during the voyage of the "Quest" on the Shackleton-Rowett Expedition to the South Atlantic \& Weddell Sea in 1921-22. Trustees of the British Museum, London. 28-54.

Wegener, A. 1912. Die Entstehung der Kontinente. Geologische Rundschau, 3, 276292.

Wegener, A. 1915. Die Entstehung der Kontinente und Ozeane. Friedrich Vieweg \& Sohn, Braunschweig. 94 pp.

Wilckens, O. 1932. Fossilien und Gesteine von Süd-Georgien. Scientific Results of the Norwegian Antarctic Expeditions 1927 -1928 and 1928 -1929, 8. I Kommisjon Hos Jacob Dybwad, Oslo. 28 pp + 3 plates.

Wordie, J. M. 1921. Shackleton Antarctic Expedition 1914-1917: geological observations in the Weddell Sea area. Transactions of the Royal Society of Edinburgh, 53, 17-27. 


\section{Figure Captions}

Figure 1. The South Atlantic and Scotia Sea region showing the areas prospected by David Ferguson: South Georgia, Falkland Islands, South Shetland Islands and adjacent coast of Graham Land.

Figure 2. Outline geology for South Georgia (after Curtis 2011) showing the location of places mentioned in the text.

Figure 3. David Ferguson (seated, centre) surrounded by the crew of the S.S. Matilda, the whale catcher that transported him around South Georgia. Grytviken, March 1912. Edinburgh University Library, Special Collections Department, Salvesen Archive reference 7628d. This is currently the only known photograph of Ferguson.

Figure 4. Large-scale overturned folds at Stromness Bay, South Georgia. These folds were seen and photographed by David Ferguson in 1912, but were not featured in his 1915 paper. They were subsequently illustrated by James Wordie (1921) in his critique of Ferguson's stratigraphy. The highest point on the skyline ridge is about $400 \mathrm{~m}$ above sea level.

Figure 5. The trace fossil Chondrites from the Cumberland Bay Formation, South Georgia. Examples of this feeding burrow pattern were described by Gregory (1915, plate 92, figures 2-6) as Camarocladia ?, a possible early Palaeozoic sponge. However, Gregory stressed that the name was tentative and “only provisionally adopted for them for convenience of reference (1915, p. 819). This photograph courtesy of Dr. Geoff Tanner.

Figure 6. The geological cross section of South Georgia drawn up by Ferguson and included in his (unpublished) confidential report to the Salvesen Company. Edinburgh University Library, Special Collections Department, Salvesen Archive reference Gen 1925, H34. 
Figure 7. A fossil ammonite from the Cumberland Bay Formation, South Georgia. Because ammonites are definitively Mesozoic, Ferguson initially decided that such fossils must be goniatites since he was convinced that the South Georgia strata were early Palaeozoic in age; he believed that goniatites might extend as far back as the Cambrian. This photograph of a recently discovered example is by courtesy of Dr. Geoff Tanner.

Figure 8. A section across a ‘Block Mountain’ as illustrated in his book The Great Rift Valley by Gregory (1896, figure 10). Note the influence of this on Ferguson's interpretation of South Georgia shown in Figure 6.

Figure 9. One of the authors (PS) near the summit of Ferguson Peak at the south-east end of South Georgia early in 1974. The view looks south-west towards the entrance to Drygalski Fjord. The foreground rock is frost-shattered mylonite within the Cooper Bay Shear Zone; more distant are igneous rocks of the Drygalski Fjord and Larsen Harbour complexes (see Figure 2).

Figure 10. Location and outline geology map for the Falkland Islands (after Aldiss \& Edwards 1999).

Figure 11. Ferguson's notebook sketch illustrating his interpretation of the geology in the Hill Cove area, on the north coast of West Falkland. He regarded the Upper Carboniferous tillite as a recent boulder accumulation filling a palaeovalley eroded into 'basement' rocks. University of Glasgow library archive: Ferguson notebook 3, p 170 (21 March 1914).

Figure 12. Ferguson's notebook sketch illustrating his interpretation of the geology in the Port Sussex area, on the west Coast of East Falkland, showing the 'Great Fault' that he believed separated the Permian strata of Lafonia from the older rocks to the north. University of Glasgow library archive: Ferguson notebook 3, pp 135-136 (12 March 1914). 
Figure 13. Edinburgh Hill, Livingston Island: Ferguson's photograph and geological sketch map after Ferguson (1921), Plate 1, figure 1 and Text-figure 6 respectively. Ferguson's use of 'Livingstone' is a mis-spelling.

Figure 14. Gregory's illustrations of 'Flabellites Land' and 'Gondwanaland' from his published presidential address to the Geological Society of London entitled The Geological History of the Atlantic Ocean (Gregory 1929, cxviii)

\section{Table Caption}

Table 1. University of Glasgow archive details for David Ferguson’s field notebooks 
Table 1. Glasgow University archive details for David Ferguson’s field notebooks

\begin{tabular}{|l|l|l|l|}
\hline Notebook number & Archive numbers & Approximate dates & Main area covered \\
\hline 1 & $\begin{array}{l}2500 / 27 \\
\text { UGC/176/3/1 }\end{array}$ & Jan-Feb 1912 & South Georgia \\
\hline 2 & $\begin{array}{l}2500 / 28 \\
\text { UGC/176/3/2 }\end{array}$ & Jan-Apr 1912 & South Georgia \\
\hline 3 & $\begin{array}{l}2500 / 29 \\
\text { UGC/176/3/3 }\end{array}$ & $\begin{array}{l}\text { Oct-Dec 1913 } \\
\text { Feb-Apr 1914 }\end{array}$ & Falkland Islands \\
\hline 4 & $\begin{array}{l}2500 / 30 \\
\text { UGC/176/3/4 }\end{array}$ & Dec 1913-Jan 1914 & $\begin{array}{l}\text { South Shetland } \\
\text { Islands }\end{array}$ \\
\hline 5 & $\begin{array}{l}2500 / 31 \\
\text { UGC/176/3/5 }\end{array}$ & Jan-Feb 1914 & $\begin{array}{l}\text { South Shetland } \\
\text { Islands }\end{array}$ \\
\hline 6 & $\begin{array}{l}\text { Jan-Feb 1914 } \\
\text { UGC/176/3/6 }\end{array}$ & $\begin{array}{l}\text { NW coast of } \\
\text { Graham Land }\end{array}$ \\
\hline
\end{tabular}




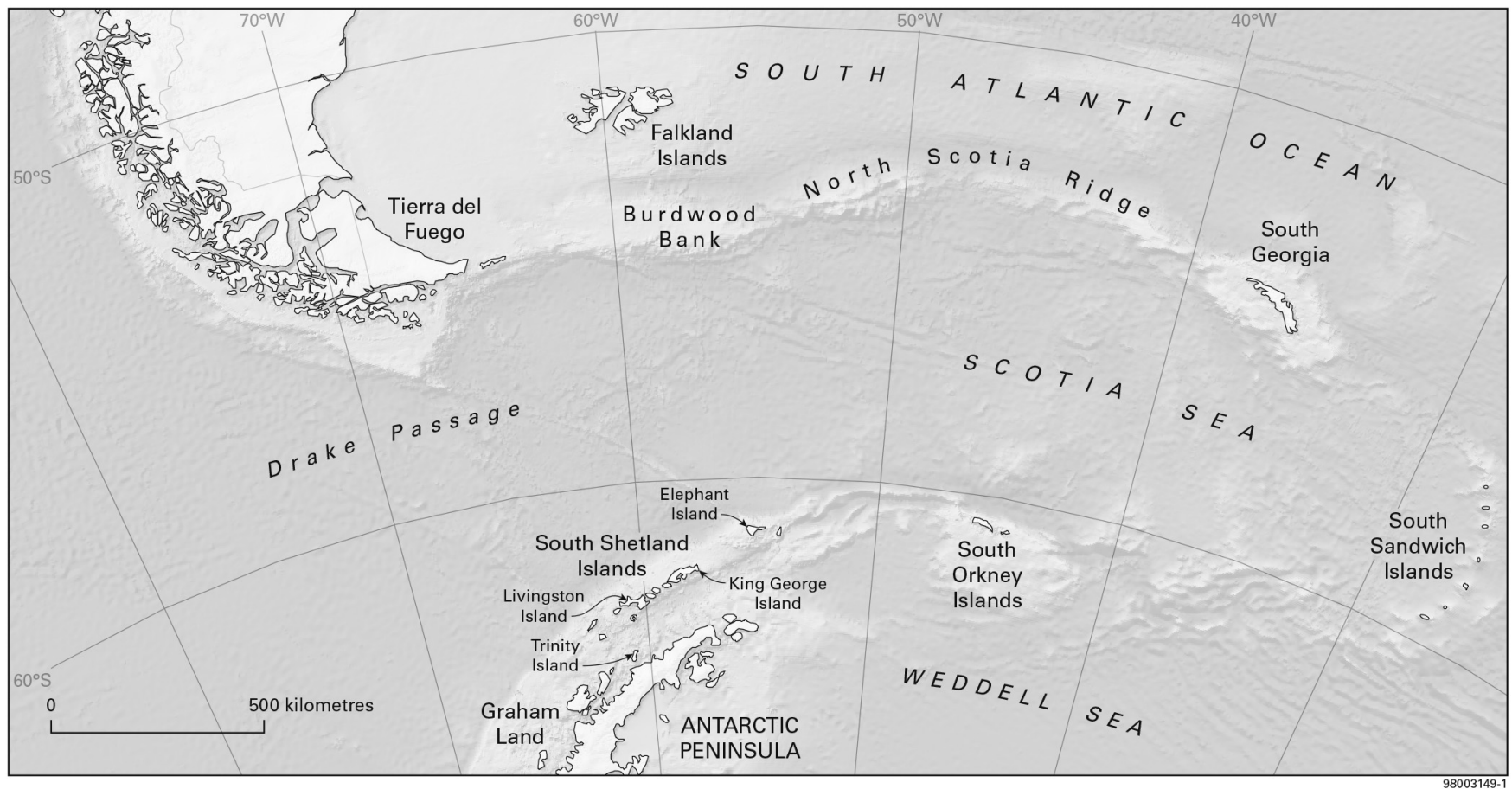




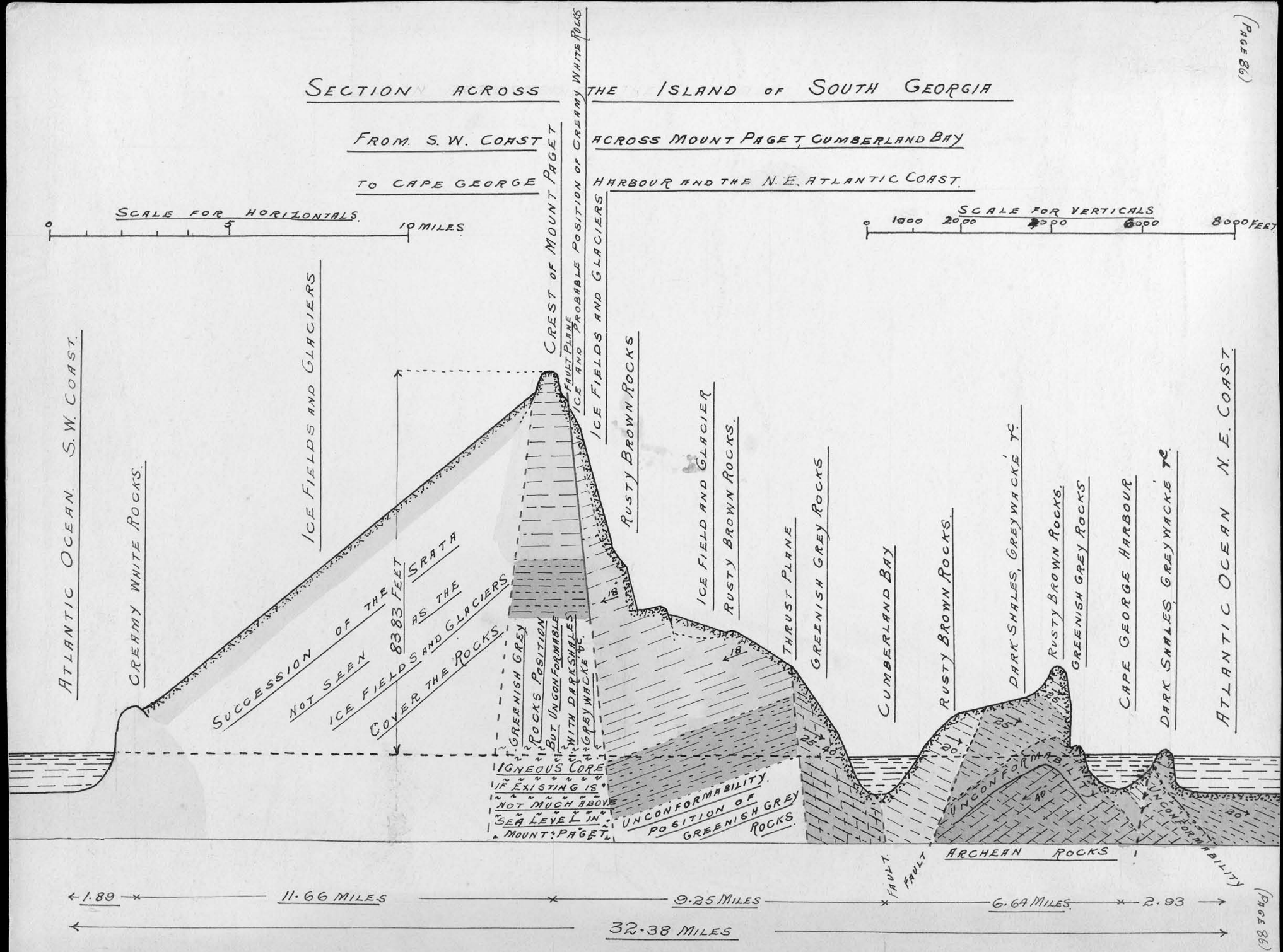




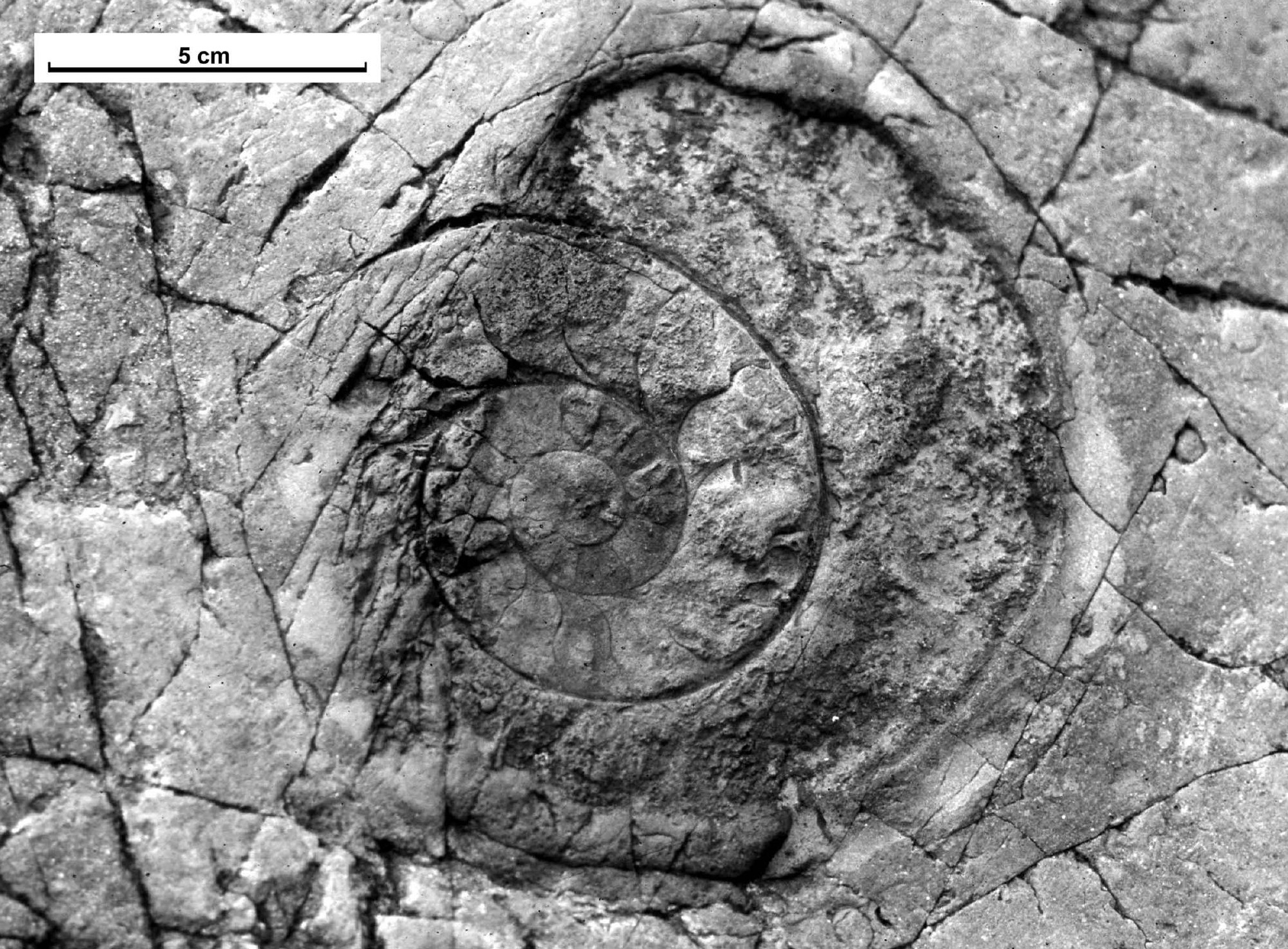




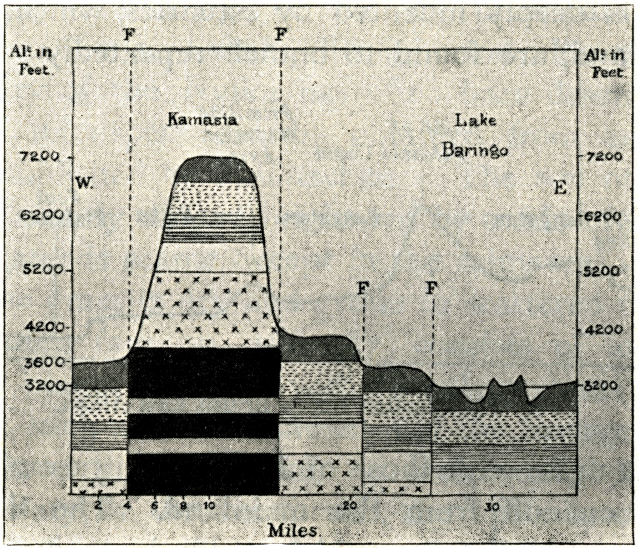

FIG. I0. -Section across a "Block Mountain." ( $F=$ Faults. $)$ 


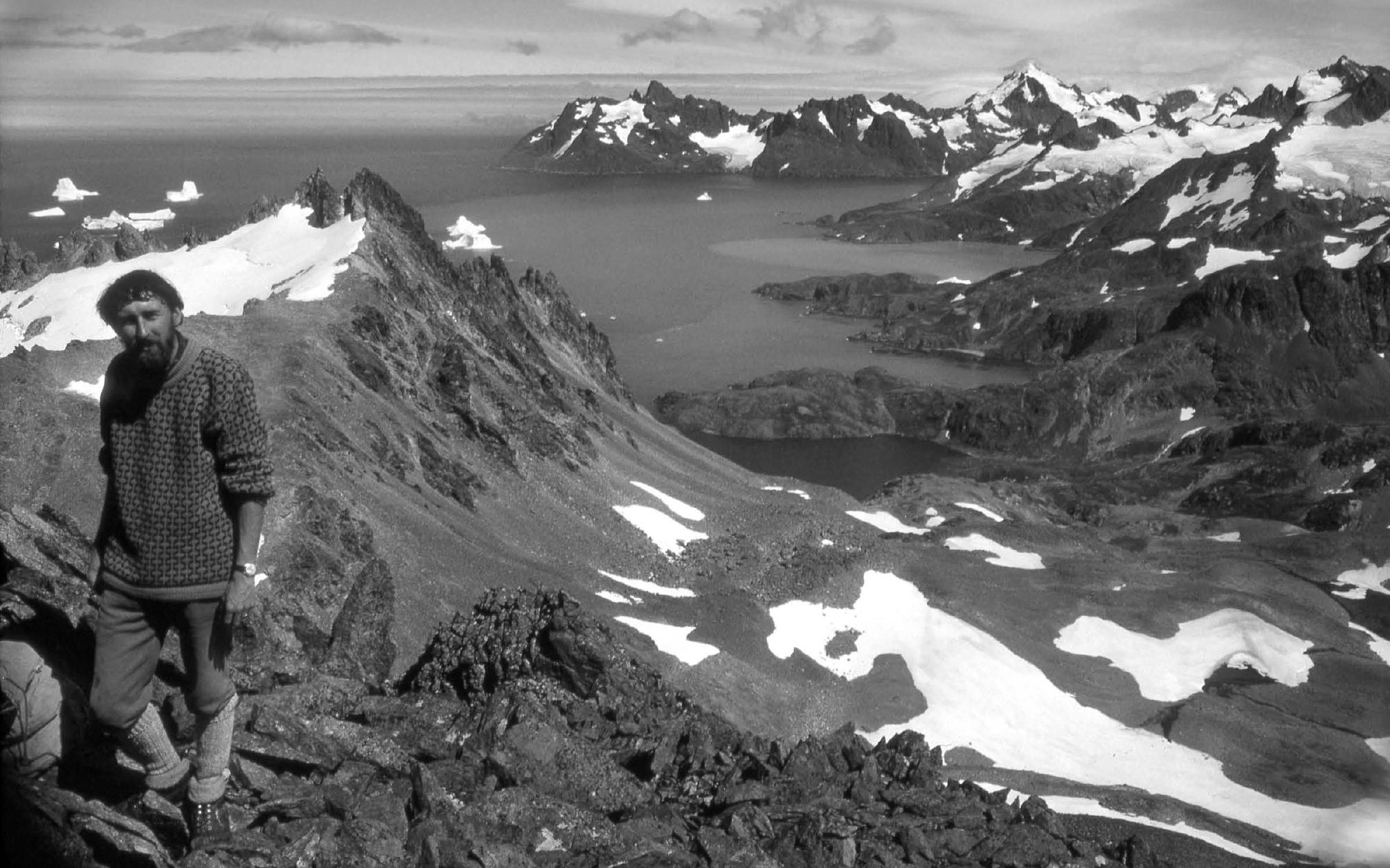




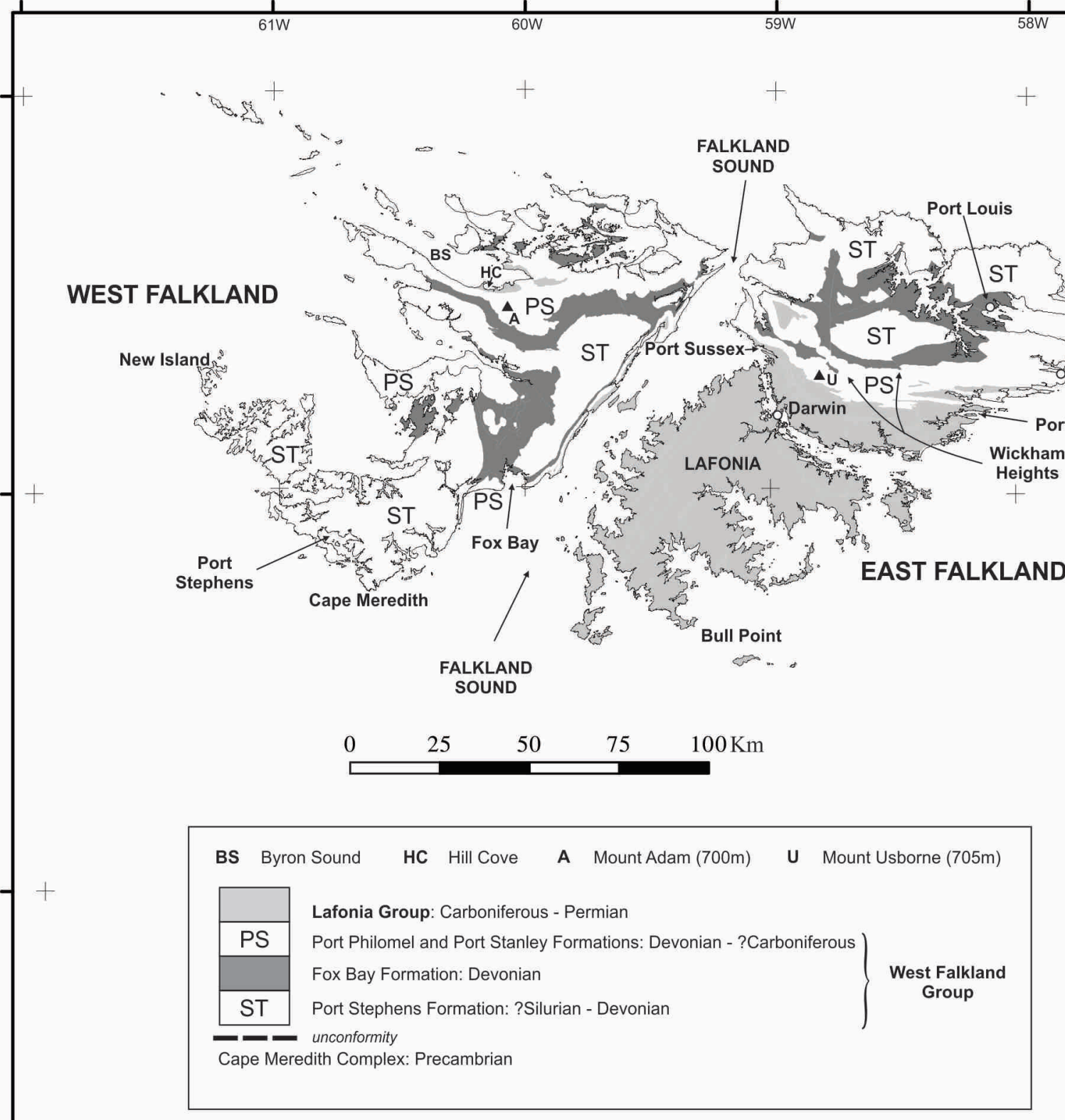




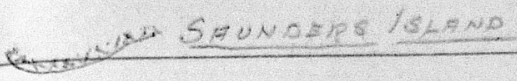

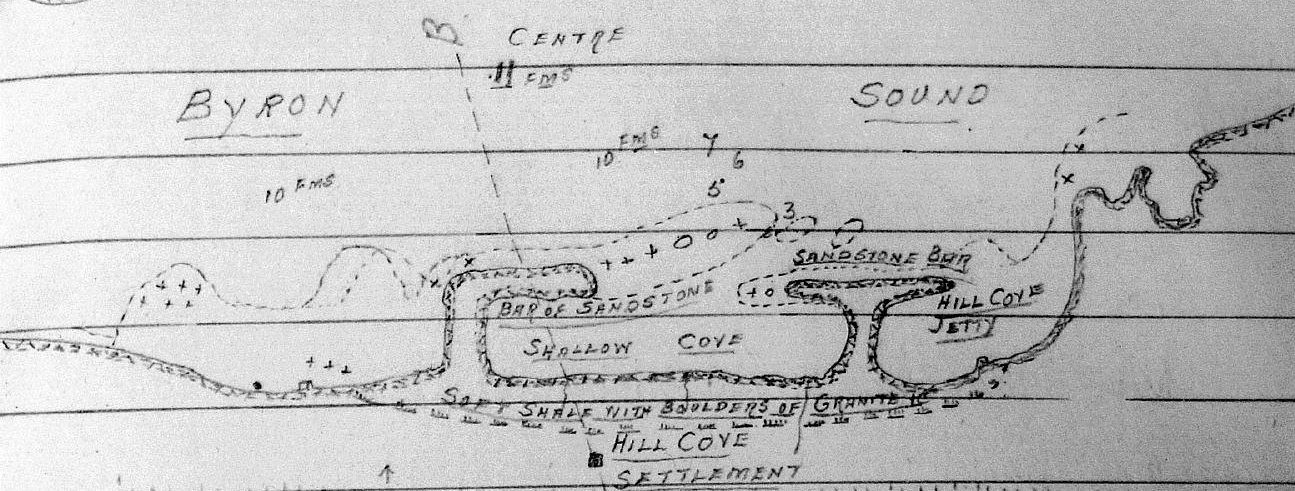

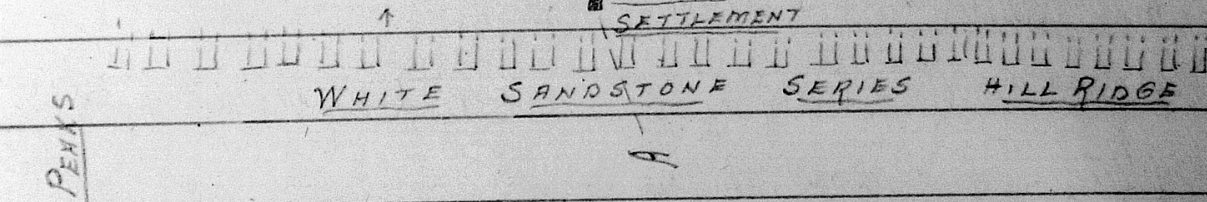

है

$\frac{2 \pi+3}{4}$

$(2) \frac{1}{3}$

$\therefore \therefore \frac{0}{3}$

$\therefore 1 . \log _{2}^{0}$

$\therefore \quad \therefore$.

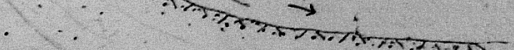

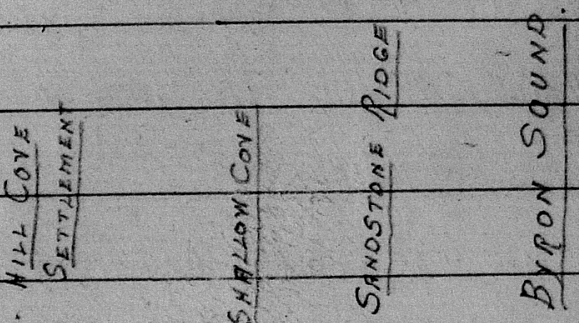

.
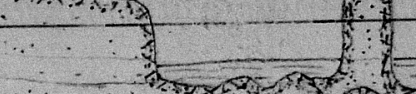

HLL COVE

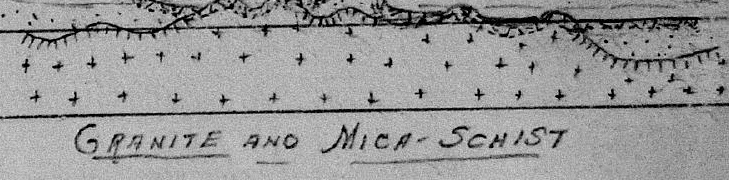

SKETOH SECTION ON LINE A. B

SAEWING ERODED CHANHEL OF BYRON SOUND

PMD PELATIYE POSITIONS OF WHITE SRNASTONE SERIES

GRANITE AND MICA-SCHIST 


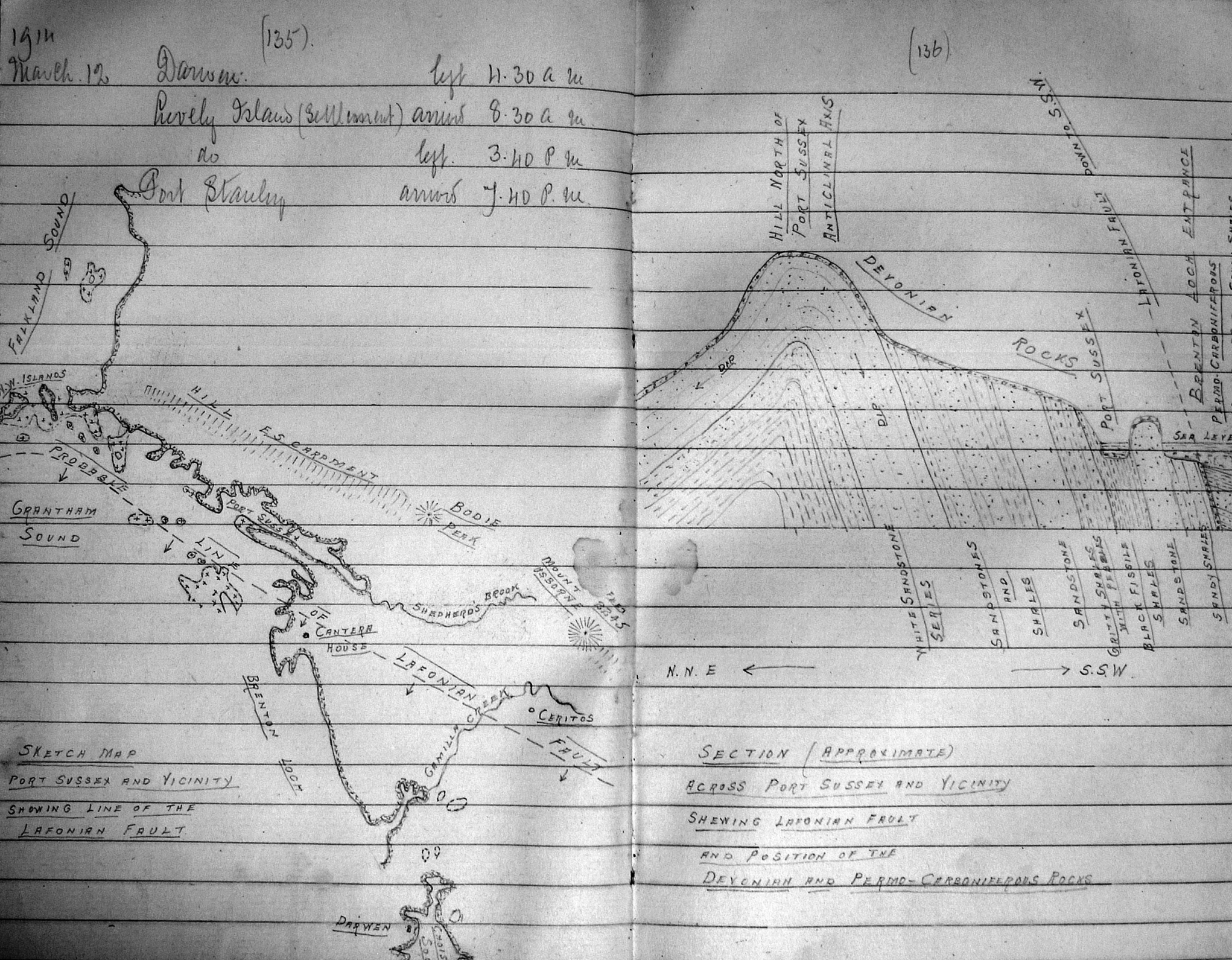




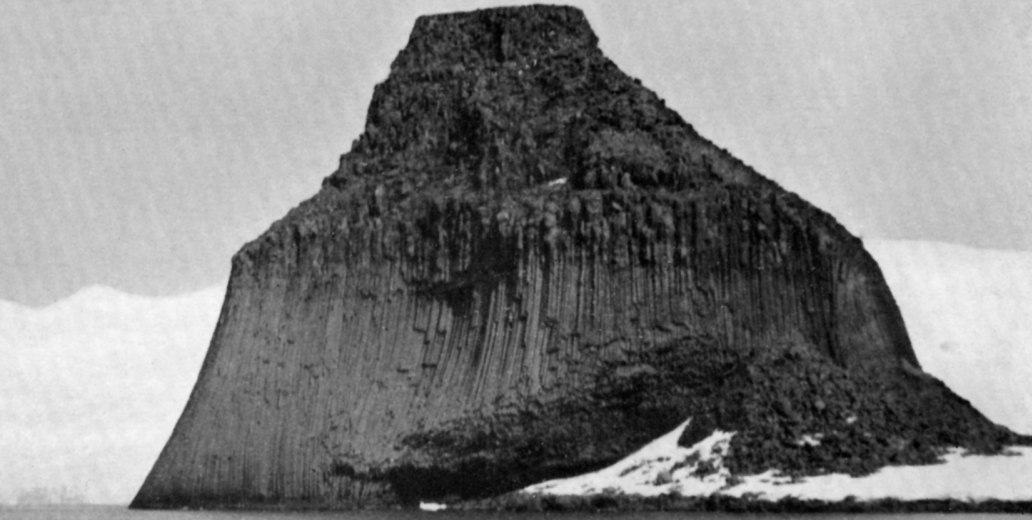




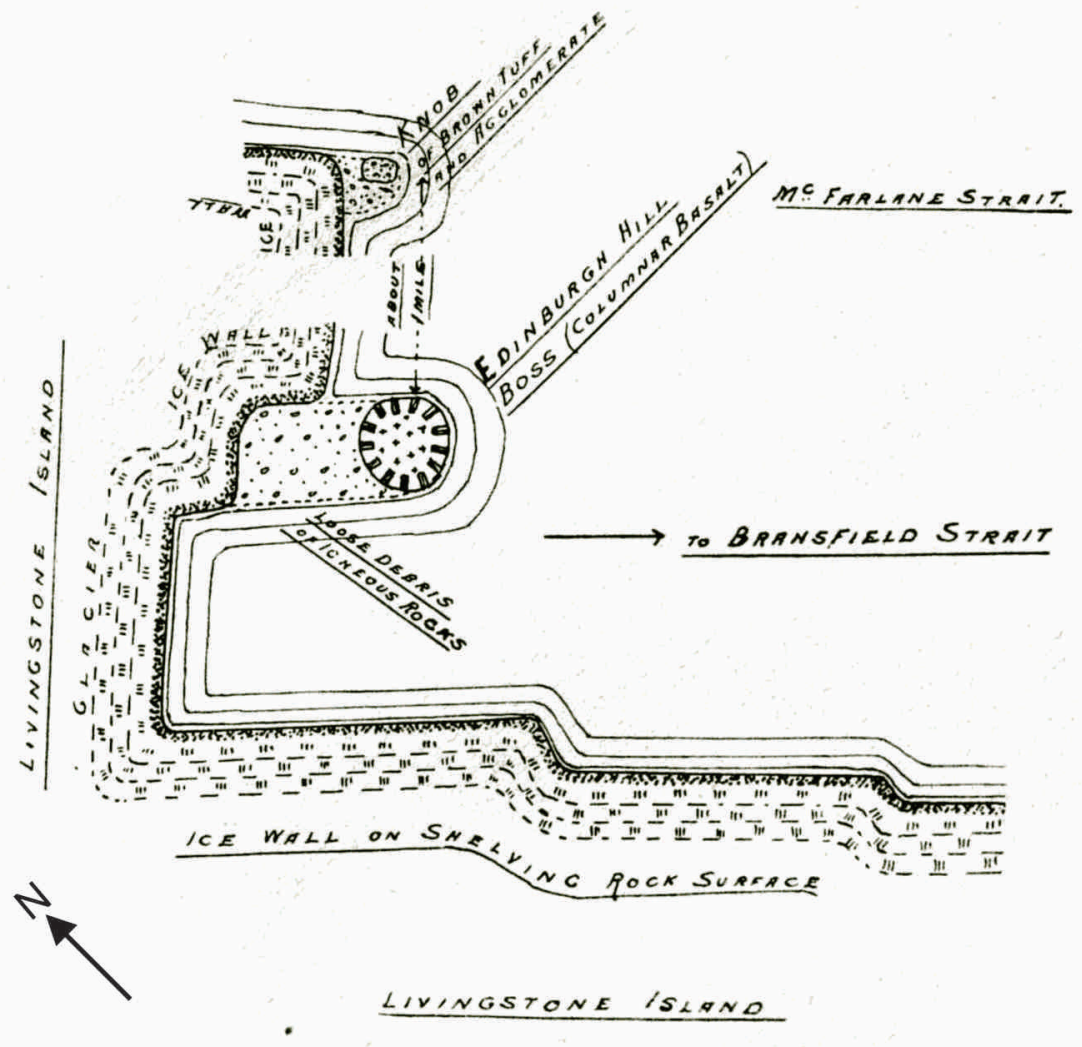


UPPER CARBONIFEROUS

MID. DEVONIAN

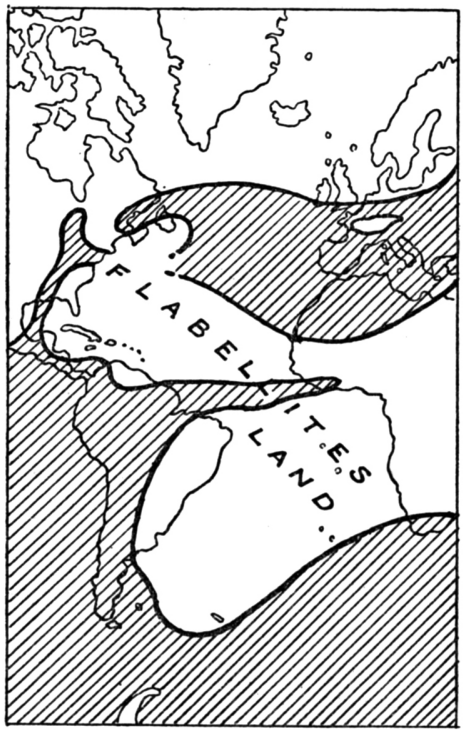

TO RHAETIC

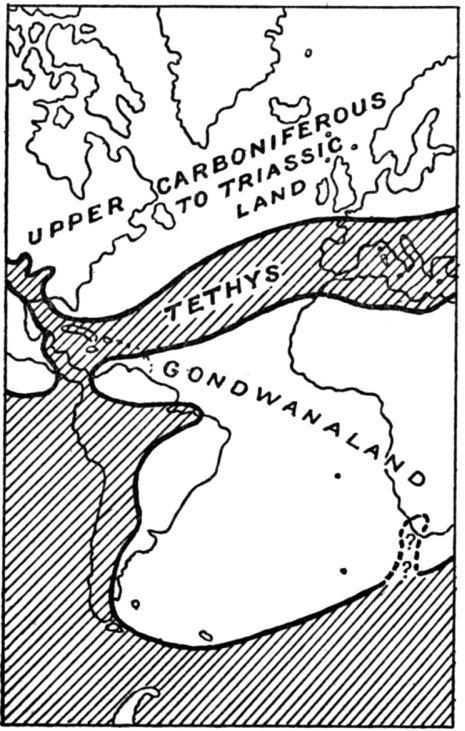

